\title{
Nanomaterial- and shape-dependency of TLR2 and TLR4 mediated signaling following pulmonary exposure to carbonaceous nanomaterials in mice
}

Pernille Høgh Danielsen ${ }^{1}$, Katja Maria Bendtsen ${ }^{1}$, Kristina Bram Knudsen ${ }^{1}$, Sarah Søs Poulsen ${ }^{1}$, Tobias Stoeger ${ }^{2}$ and Ulla Vogel ${ }^{1,3^{*}}$ (D)

\begin{abstract}
Background: Pulmonary exposure to high doses of engineered carbonaceous nanomaterials (NMs) is known to trigger inflammation in the lungs paralleled by an acute phase response. Toll-like receptors (TLRs), particularly TLR2 and TLR4, have recently been discussed as potential NM-sensors, initiating inflammation. Using T/r2 and T/r4 knock out (KO) mice, we addressed this hypothesis and compared the pattern of inflammation in lung and acute phase response in lung and liver $24 \mathrm{~h}$ after intratracheal instillation of three differently shaped carbonaceous NMs, spherical carbon black (CB), multi-walled carbon nanotubes (CNT), graphene oxide (GO) plates and bacterial lipopolysaccharide (LPS) as positive control.

Results: The LPS control confirmed a distinct TLR4-dependency as well as a pronounced contribution of TLR2 by reducing the levels of pulmonary inflammation to 30 and $60 \%$ of levels in wild type (WT) mice. At the doses chosen, all NM caused comparable neutrophil influxes into the lungs of WT mice, and reduced levels were only detected for GO-exposed T/r2 KO mice (35\%) and for CNT-exposed T/r4 KO mice (65\%). LPS-induced gene expression was strongly TLR4-dependent. CB-induced gene expression was unaffected by TLR status. Both GO and MWCNT-induced Saa 1 expression was TLR4-dependent. GO-induced expression of CxC12, CxC15, Saa1 and Saa3 were TLR2-dependent. NMmediated hepatic acute phase response in terms of liver gene expression of Saa 1 and Lcn2 was shown to depend on TLR2 for all three NMs. TLR4, in contrast, was only relevant for the acute phase response caused by CNTs, and as expected by LPS.
\end{abstract}

Conclusion: TLR2 and TLR4 signaling was not involved in the acute inflammatory response caused by CB exposure, but contributed considerably to that of GO and CNTs, respectively. The strong involvement of TLR2 in the hepatic acute phase response caused by pulmonary exposure to all three NMs deserves further investigations.

Keywords: Toll-like receptors, Nanomaterials, Inflammation, Acute phase response, Knockout mice

*Correspondence: ubv@nrcwe.dk

${ }^{1}$ National Research Centre for the Working Environment, Copenhagen, Denmark

Full list of author information is available at the end of the article

\section{Background}

Carbonaceous nanomaterials (NMs) including carbon black $(\mathrm{CB})$, carbon nanotubes (CNTs) and graphene oxide (GO) are commonly produced and applied in a wide range of industrial and consumer products [1-3]. Potential occupational exposure of workers via original author(s) and the source, provide a link to the Creative Commons licence, and indicate if changes were made. The images or other third party material in this article are included in the article's Creative Commons licence, unless indicated otherwise in a credit line to the material. If material is not included in the article's Creative Commons licence and your intended use is not permitted by statutory regulation or exceeds the permitted use, you will need to obtain permission directly from the copyright holder. To view a copy of this licence, visit http://creativecommons.org/licenses/by/4.0/. The Creative Commons Public Domain Dedication waiver (http://creativeco mmons.org/publicdomain/zero/1.0/) applies to the data made available in this article, unless otherwise stated in a credit line to the data. 
inhalation can lead to adverse health effects and cause lung inflammation as well as systemic effects [4].

The interaction of NMs with the innate immune system is important for recognition and elimination, which provides the first line of defense against foreign material in the body [5, 6]. It has been hypothesized that the innate immune system sense NMs directly or via surface-adsorbed biomolecules by pattern recognition receptors (PRRs) on the cell surface. Toll-like receptors (TLRs) belong to the family of PRRs and are activated upon binding with several ligands, often referred to as senses pathogen-associated molecular patterns (PAMPs) and damage-associated molecular patterns (DAMPs) [7] initiating a signaling cascade leading to the release of cytokines and chemokines which recruits immune cells [8]. In the airways, TLR2 and TLR4 are the most relevant TLRs, and these play a critical role in the progression of pulmonary diseases [9, 10]. TLR4 is well known for its recognition of bacterial lipopolysaccharide (LPS) [11], whereas TLR2 recognizes lipoproteins from various pathogens [12]. However, TLR2 and TLR4 also recognize endogenous host-derived DAMP ligands, usually produced or released as result of tissue injury [13]. DAMPs released from cells following tissue injury or cell death can be recognized by macrophages and can thus trigger the inflammatory response by different pathways, including TLR [14]. Different DAMPs interact with different TLR receptors, e.g. heat shock proteins (TLR2, TLR4), HMGB1 (TLR2, TLR4, (also RAGE)) and SAA (TLR2) [13]. Carbonaceous NMs (C60, SWCNT and GO) were found to cause release of HMGB1 from mice lung cells, especially macrophages, leading to activation of the RAGE pathway (TLR pathway was not investigated) [15]. Gold nanoparticles were found to bind HMGB1 in the lysosomes of macrophages, which were associated with inhibition of TLR9 function, other TLRs were not investigated [16]. The coarse and fine fractions of airborne particulate matter caused induction of the heat shock protein 70 in vitro, whereas the ultrafine fraction did not [17]. TLR2 has furthermore been proposed to be a functional receptor for the acute phase protein serum amyloid A (SAA) [18]. Different isoforms of SAA exists; in both mice and humans, SAA1 and SAA2 are inducible by inflammatory cytokines [19], but whereas Saa3 is considered a pseudogene in humans, it is the most differentially regulated gene in lung tissue of mice exposed to various types of NMs [20-23]. Acute phase response is an established risk factor for cardiovascular disease in a prospective epidemiological study [24]. Acute phase response and the accompanying inflammatory response are strongly associated to increased risk of atherosclerosis [19, 20, 25].
Few studies have investigated the possible direct interaction between NMs and TLRs. Computational studies indicate that carbon nanostructures such as present on C60 or CNTs might bind to the internal hydrophobic pockets of some TLRs, in particular TLR2, and TLR4 [26]. One study suggests that single-walled CNTs trigger chemokine production through a direct interaction with TLR4 [27], another study using gold nanoparticles suggests that the inflammatory response in lung epithelial cells was induced following SAA1-TLR2 ligand-receptor interaction [28].

Previous studies show that pulmonary exposure to poorly soluble carbon-based nanoparticles, such as $\mathrm{CB}$, induce a dose-dependent neutrophil influx and pulmonary acute phase response at day 1 post-exposure that declines over time [29-31]. In contrast, pulmonary exposure to differently shaped CNTs and GO induce a stronger dose-dependent neutrophil influx and pulmonary acute phase response that continues to increase until day 3 , and the pulmonary response is accompanied by a hepatic acute phase response 1 day post-exposure [32-36]. It has been speculated that the bending structure of GO may trigger TLR activation or that GO, with a high level of hydroxylation, may trigger similar responses as LPS [35]. The observed differences in response may be due to differences in the interaction with cells and the subsequent initiation of the inflammatory response following exposure to NMs, however, the initiating mechanisms are largely unknown.

In the present study, we hypothesize that inflammatory and acute phase responses can be mediated by different signaling pathways, and we furthermore hypothesize that CNT and GO may initiate a physicochemical-dependent inflammatory response which is mediated, at least partially, by the same TLR-dependent signaling pathway as LPS, whereas CB-induced inflammation presumably is not. In order to investigate this, we performed (1) two pilot studies in mice using the TLR-antagonist Sparstolonin B (methods and results are found in Additional file 1) and subsequently (2) the main study where we exposed Tlr4 and Tlr2 knockout (KO) mice to CB, CNT, GO and LPS by intratracheal (i.t) instillation and compared the response to wild type (WT) mice. The influx of inflammatory cells in the lungs, expression of inflammation markers and acute phase response in lung and liver were assessed 1 day post-exposure.

\section{Results}

\section{Characterization of the NMs}

The key physico-chemical characteristics of the NMs are summarized in Table 1. Dynamic light scattering was used to determine the hydrodynamic number-based size distributions of NMs in the instillation suspensions 


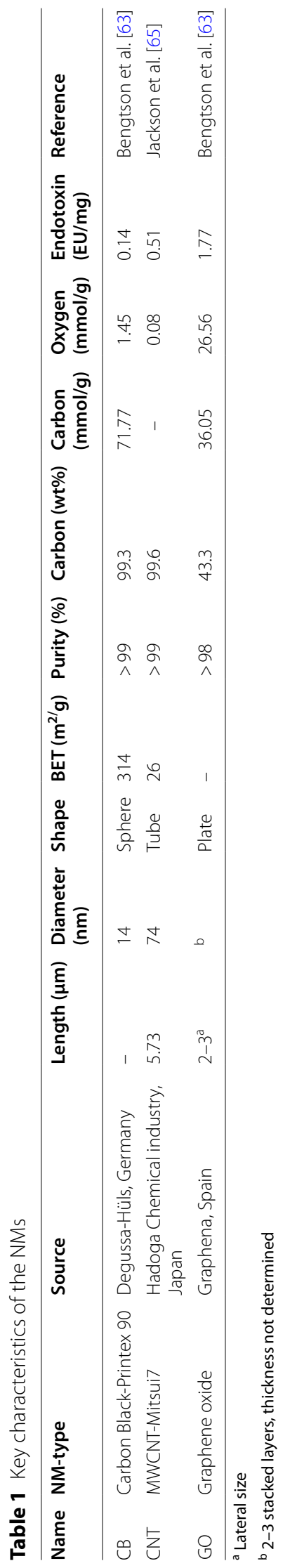


(3.24 mg/ml in Nanopure Diamond water with $2 \%$ mouse serum). The hydrodynamic number-based size distribution showed unimodal peaks for CB and CNT at $44 \mathrm{~nm}$ and $342 \mathrm{~nm}$, respectively and was slightly bimodal for GO showing a small peak at $28 \mathrm{~nm}$ and a larger around $73 \mathrm{~nm}$ (Additional file 1: Fig. S1). The intensity-based size distributions are shown in Additional file 1: Fig. S2. The $\mathrm{z}$-average size and polydispersity index are shown in Table S1 (Additional file 1).

The dose levels of CB $(162 \mu \mathrm{g})$, CNT $(54 \mu \mathrm{g})$ and GO $(18 \mu \mathrm{g})$ were selected based on previous studies [35, 37] to induce comparable levels of inflammation but not overt toxicity in terms of alveolar injury and systemic toxicity e.g. weight loss. Protein content in BAL fluid was used as biomarker of lung toxicity and alveolar barrier integrity. The protein content was unaffected by exposure and mouse $\mathrm{Tlr}$ status, indicating that the exposures did not induce overt toxicity (Additional file 1: Fig. S3).

\section{Cell composition in BAL fluid}

Influx of inflammatory cells; total number of cells and number of macrophages, lymphocytes, neutrophils, eosinophils and epithelial, in BAL fluid was assessed to monitor the cellular dynamics of the pulmonary inflammatory response. All data are presented in Tables 2 and 3. As expected, the number of total BAL cells, mainly driven by the influx of neutrophils, were significantly increased in WT and Tlr2 $\mathrm{KO}$ mice, but not Tl4 $\mathrm{KO}$ mice after exposure to LPS when compared to the vehicle control. In contrast, all NMs provoked BAL neutrophil levels exceeding control conditions, but the range of increases depended on $\mathrm{Tl} r$ genotypes. Differences in neutrophil numbers were observed between WT mice and the $\mathrm{KO}$ mice, where CNT-exposed Tlr4 $\mathrm{KO}$ mice showed a significant decrease of $65 \%$ and GO-exposed Tlr2 $\mathrm{KO}$ mice a decrease of 35\% (Fig. 1). Interestingly, BAL eosinophil numbers were increased only upon CB-exposure in WT mice (Tables 2 and 3). Additionally, BAL macrophage numbers decreased to levels below $50 \%$ of control for CB-exposed WT mice (Tables 2 and 3).

\section{Inflammatory markers}

Pulmonary inflammation was also assessed by quantifying Il-6, Tnf, Cxcl2 and Cxcl5 mRNA expression levels in lung tissue.

Different types of NMs upregulate the pro-inflammatory genes $\mathrm{Il}-6$ and Tnf in various studies [38-42] and these are among the important cytokines of the acute phase response [43].

As observed on the level of BAL cells, LPS caused a strong pro-inflammatory signature for all genes in WT and Tlr2 $\mathrm{KO}$ mice, but not Tlr4 $\mathrm{KO}$ mice. Overall, NMexposure increased $I l-6$ and $T n f$ mRNA expression levels (Fig. 2A-D, respectively), though predominantly for $I l-6$, and the $I l-6$ and $\operatorname{Tn} f$ mRNA levels correlate closely across exposures and Tlr status $(\mathrm{r}=0.8370, \mathrm{P} \leq 0.0001)$ (Additional file 1: Fig. S4). The pro-inflammatory response following NM exposure in terms of Il-6 and Tnf expression was different from the LPS response. Whereas LPSmediated expression depended on TLR4 (Fig. 2B, 2D) and

Table 2 BAL cell counts in mice $24 \mathrm{~h}$ post exposure

\begin{tabular}{|c|c|c|c|c|c|}
\hline & Control & LPS & CB & CNT & GO \\
\hline & $0 \mu g$ & $4 \mu g$ & $162 \mu \mathrm{g}$ & $54 \mu \mathrm{g}$ & $18 \mu \mathrm{g}$ \\
\hline \multicolumn{6}{|l|}{ WT } \\
\hline Total BAL cells $\left(\times 10^{3}\right)$ & $73.1 \pm 34.9$ & $824 \pm 404^{* * *}$ & $191 \pm 61.2^{* *}$ & $151 \pm 33.6^{* *}$ & $293 \pm 85.9^{* * *}$ \\
\hline Macrophages $\left(\times 10^{3}\right)$ & $59.9 \pm 19.3$ & $76.8 \pm 47.3$ & $23.9 \pm 15.4^{* *}$ & $50.8 \pm 8.74$ & $52.4 \pm 13.9$ \\
\hline Lymphocytes $\left(\times 10^{3}\right)$ & $0.51 \pm 0.45$ & $6.14 \pm 6.96$ & $1.30 \pm 1.35$ & $2.20 \pm 1.51$ & $1.61 \pm 1.10$ \\
\hline Neutrophils $\left(\times 10^{3}\right)$ & $4.75 \pm 4.93$ & $724 \pm 338^{* *}$ & $133 \pm 45.4^{* * *}$ & $70.8 \pm 31.9^{* *}$ & $218 \pm 73.9^{* *}$ \\
\hline Eosinophils $\left(\times 10^{3}\right)$ & $8.30 \pm 22.8$ & $1.37 \pm 3.06$ & $28.2 \pm 23.4^{* *}$ & $21.3 \pm 15.0^{*}$ & $17.1 \pm 9.82^{*}$ \\
\hline Epithelial $\left(\times 10^{3}\right)$ & $4.40 \pm 3.60$ & $15.6 \pm 14.7^{*}$ & $5.52 \pm 3.95$ & $5.61 \pm 1.94$ & $4.13 \pm 2.65$ \\
\hline \multicolumn{6}{|l|}{ TIr2 KO } \\
\hline Total BAL cells $\left(\times 10^{3}\right)$ & $73.1 \pm 34.9$ & $475 \pm 106^{* * *}$ & $184 \pm 31.0^{* *}$ & $133 \pm 47.7^{*}$ & $239 \pm 33.2^{* *}$ \\
\hline Macrophages $\left(\times 10^{3}\right)$ & $59.9 \pm 19.3$ & $30.1 \pm 17.9^{*}$ & $27.1 \pm 17.3^{*}$ & $35.9 \pm 18.6$ & $81.4 \pm 22.9$ \\
\hline Lymphocytes $\left(\times 10^{3}\right)$ & $0.51 \pm 0.45$ & $1.27 \pm 1.47$ & $4.19 \pm 2.32^{* *, a}$ & $2.65 \pm 2.93^{*}$ & $6.46 \pm 7.70$ \\
\hline Neutrophils $\left(\times 10^{3}\right)$ & $4.75 \pm 4.93$ & $405 \pm 66.0^{* *}$ & $140 \pm 31.9^{* *}$ & $60.0 \pm 13.5^{* *}$ & $140 \pm 44.1^{* *}$ \\
\hline Eosinophils $\left(\times 10^{3}\right)$ & $8.30 \pm 22.8$ & $0.00 \pm 0.00$ & $9.65 \pm 7.75^{*}$ & $27.0 \pm 37.5^{*}$ & $8.45 \pm 10.8^{*}$ \\
\hline Epithelial $\left(\times 10^{3}\right)$ & $4.40 \pm 3.60$ & $3.29 \pm 3.23$ & $3.13 \pm 1.22$ & $7.34 \pm 3.93$ & $6.05 \pm 1.27$ \\
\hline
\end{tabular}

All values are presented as mean $\pm S D$. There are no statistical significant difference between the vehicle controls, therefore these are pooled in the statistical analyses $\left(\mathrm{WT}+\right.$ T/r2 KO). A symbol $\left({ }^{*}\right)$ denotes $\mathrm{P} \leq 0.05,\left({ }^{* *}\right) \mathrm{P} \leq 0.01,\left({ }^{* *}\right) \mathrm{P} \leq 0.001$ compared to vehicle control. Comparing T/r2 KO and WT, a letter $\left({ }^{\mathrm{a}}\right)$ denotes $\mathrm{P} \leq 0.05,\left({ }^{b}\right)$ $\mathrm{P} \leq 0.01$ 
Table 3 BAL cell counts in mice $24 \mathrm{~h}$ post exposure

\begin{tabular}{|c|c|c|c|c|c|}
\hline & Control & LPS & $\mathrm{CB}$ & CNT & GO \\
\hline & $0 \mu \mathrm{g}$ & $4 \mu g$ & $162 \mu \mathrm{g}$ & $54 \mu \mathrm{g}$ & $18 \mu \mathrm{g}$ \\
\hline \multicolumn{6}{|l|}{ WT } \\
\hline Total BAL cells $\left(\times 10^{3}\right)$ & $89.6 \pm 56.3$ & $824 \pm 404^{* * *}$ & $191 \pm 61.2^{* *}$ & $151 \pm 33.6^{*}$ & $293 \pm 85.9^{* *}$ \\
\hline Macrophages $\left(\times 10^{3}\right)$ & $67.2 \pm 22.6$ & $76.8 \pm 47.3$ & $23.9 \pm 15.4^{* * *}$ & $50.8 \pm 8.74$ & $52.4 \pm 13.9$ \\
\hline Lymphocytes $\left(\times 10^{3}\right)$ & $0.34 \pm 0.31$ & $6.14 \pm 6.96$ & $1.30 \pm 1.35$ & $2.20 \pm 1.51^{*}$ & $1.61 \pm 1.10^{*}$ \\
\hline Neutrophils $\left(\times 10^{3}\right)$ & $12.8 \pm 26.9$ & $724 \pm 338^{* *}$ & $133 \pm 45.4^{* * *}$ & $70.8 \pm 31.9^{*}$ & $218 \pm 73.9^{* *}$ \\
\hline Eosinophils $\left(\times 10^{3}\right)$ & $10.2 \pm 22.4$ & $1.37 \pm 3.06$ & $28.2 \pm 23.4^{*}$ & $21.3 \pm 15.0$ & $17.1 \pm 9.82$ \\
\hline Epithelial $\left(\times 10^{3}\right)$ & $5.98 \pm 3.86$ & $15.6 \pm 14.7$ & $5.52 \pm 3.95$ & $5.61 \pm 1.94$ & $4.13 \pm 2.65$ \\
\hline \multicolumn{6}{|l|}{ T/r4 KO } \\
\hline Total BAL cells $\left(\times 10^{3}\right)$ & $89.6 \pm 56.3$ & $295 \pm 423$ & $178 \pm 43.1^{*}$ & $53.2 \pm 33.4^{b}$ & $293 \pm 82.0^{* *}$ \\
\hline Macrophages $\left(\times 10^{3}\right)$ & $67.2 \pm 22.6$ & $66.8 \pm 28.4$ & $14.8 \pm 7.30^{* *}$ & $21.2 \pm 19.5^{* *, a}$ & $50.7 \pm 13.8$ \\
\hline Lymphocytes $\left(\times 10^{3}\right)$ & $0.34 \pm 0.31$ & $0.21 \pm 0.42$ & $1.50 \pm 0.92^{*}$ & $0.70 \pm 0.61$ & $0.82 \pm 0.79$ \\
\hline Neutrophils $\left(\times 10^{3}\right)$ & $12.8 \pm 26.9$ & $219 \pm 411$ & $135 \pm 31.5^{* *}$ & $23.9 \pm 11.2^{*, a}$ & $217 \pm 78.9^{* *}$ \\
\hline Eosinophils $\left(\times 10^{3}\right)$ & $10.2 \pm 22.4$ & $5.80 \pm 8.67$ & $21.4 \pm 15.9^{*}$ & $5.03 \pm 2.84$ & $19.4 \pm 14.8$ \\
\hline Epithelial $\left(\times 10^{3}\right)$ & $5.98 \pm 3.86$ & $3.50 \pm 4.05$ & $4.63 \pm 2.47$ & $2.36 \pm 1.70$ & $5.48 \pm 6.31$ \\
\hline
\end{tabular}

All values are presented as mean $\pm S D$. There were no statistical significant difference between the vehicle controls, therefore these were pooled in the statistical analyses (WT + Tlr4 KO). A symbol (*) denotes $\mathrm{P} \leq 0.05,\left(^{* *}\right) \mathrm{P} \leq 0.01,(* *) \mathrm{P} \leq 0.001$ compared to vehicle control. Comparing T/r4 KO and WT, a letter $\left({ }^{\mathrm{a}}\right)$ denotes $P \leq 0.05,\left({ }^{b}\right) P \leq 0.01$

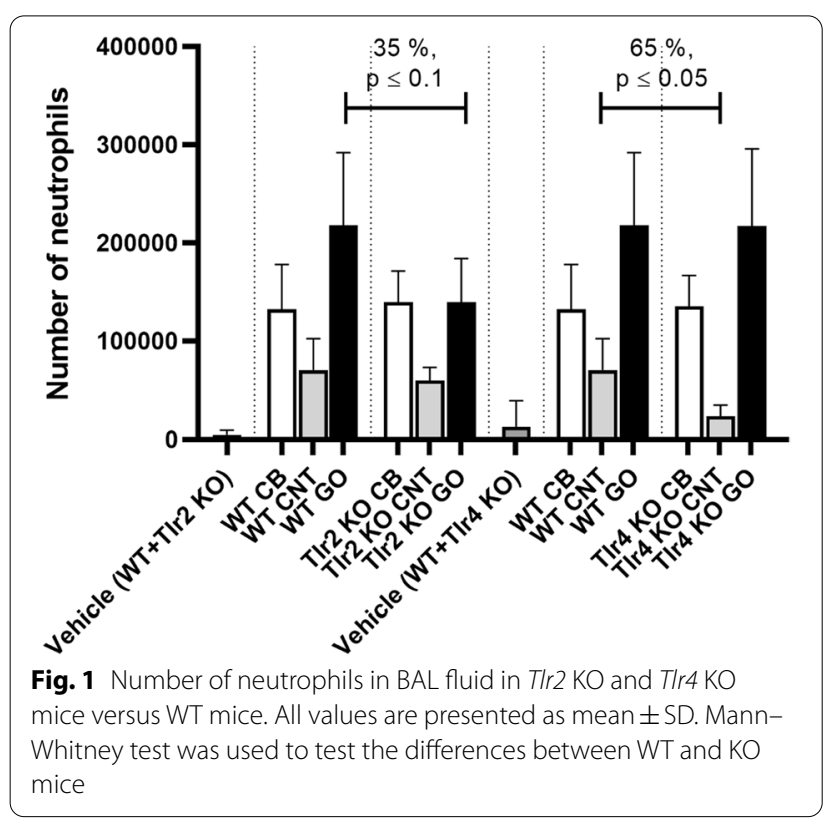

was independent of TLR2 (Fig. 2A, C), NM-mediated Il-6 and Tnf were independent of TLR4 (Fig. 2B, C), and GOmediated Tnf expression was TLR2 dependent (Fig. 2C). Furthermore, TLR4 deletion increased CB-mediated Tnf expression (Fig. 2D) and TLR2 deletion increased CNTmediated $I l-6$ expression (Fig. 2A).

Cxcl2 (MIP-2 (macrophage inflammatory protein 2)) and $\mathrm{Cxcl} 5$ are both important chemokines for neutrophil recruitment [44]. Increased Cxcl5 mRNA levels have been observed in mouse lung after exposure to $\mathrm{CB}$ and titanium dioxide $[21,29]$. Cxcl5 can under sterile conditions, such as upon $\mathrm{CB}$ exposure, be related to epithelial inflammation [45], while Cxcl2 is mainly expressed by leukocytes such as macrophages. NM and LPS exposure significantly increased the $\mathrm{Cxcl} 2$ and $\mathrm{Cxcl} 5 \mathrm{mRNA}$ levels for all mouse strains, however a significant decrease was observed for GO-induced levels in Tlr2 $\mathrm{KO}$ mice compared to WT mice (Fig. 3A, C). Thus, Cxcl2 and Cxcl5 followed the same expression pattern as $\operatorname{Tnf}$ and $\mathrm{Il}-6$ and showed a high correlation across exposures and mouse strains $(r=0.8730, P=<0.0001)$ (Additional file 1: Fig. S5). Additionally, $\mathrm{Cxcl} 2$ and $\mathrm{Cxcl5}$ plotted as function of Tnf and $I l-6$ showed high correlations (Additional file 1: Fig. S6).

\section{Pulmonary acute phase response}

Pulmonary acute phase response was assessed by $\mathrm{Saa} 3$ mRNA expression levels in lung tissue [4, 20, 25]. Saa3 gene expression was significantly increased for all exposure groups and mouse strains compared to the vehicle control $(\mathrm{P}<0.0001)$ (Fig. 4). Again, when exposed to LPS, the level of Saa3 mRNA was significantly decreased for the Tlr4 $\mathrm{KO}$ mice compared to WT mice $(\mathrm{P}<0.01)$ (Fig. 4B). Interestingly, upon exposure to GO, Saa3 mRNA levels were significantly decreased for Tlr2 KO mice, but increased for Tlr4 $\mathrm{KO}$ mice as compared to WT mice (both $\mathrm{P}<0.01$ ) (Fig. 4). 


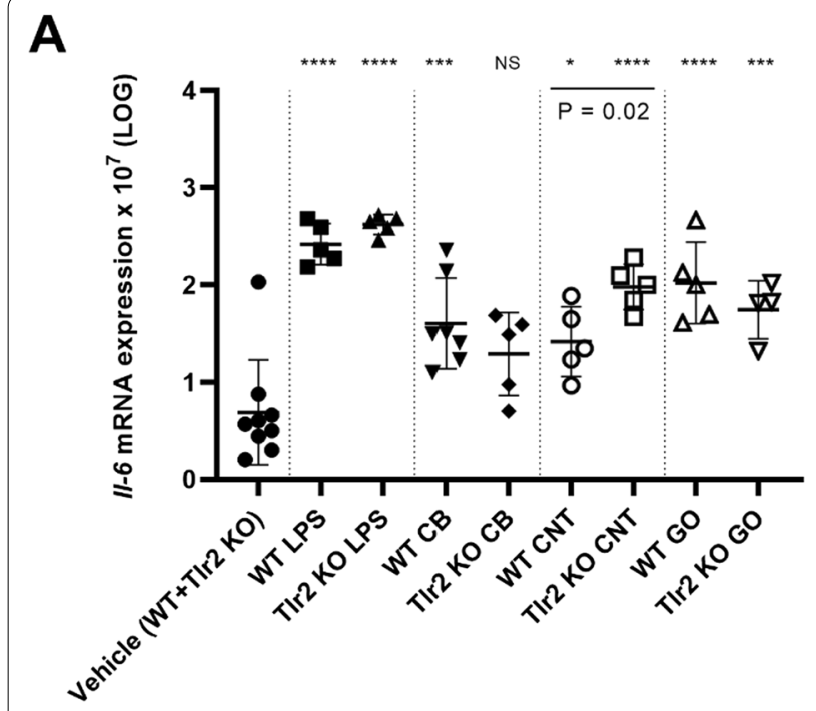

Mouse strain and exposure

C

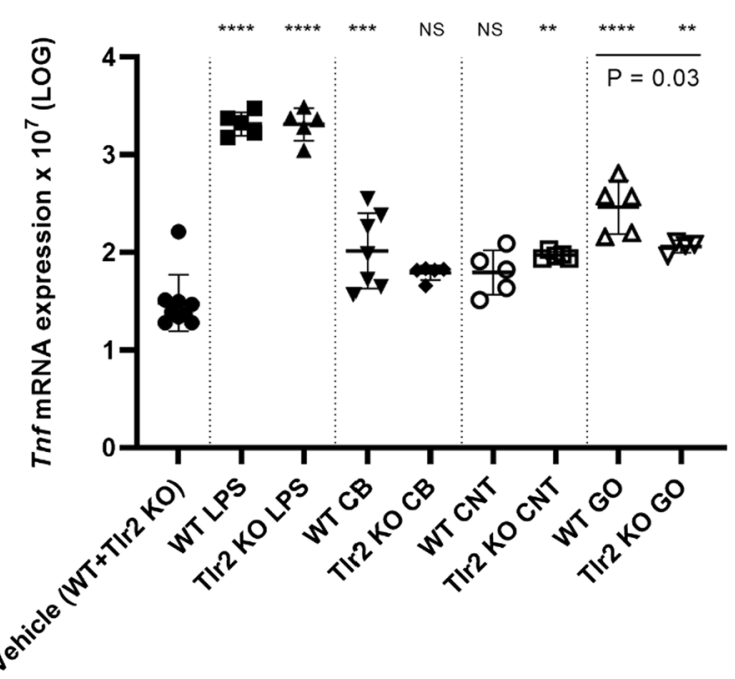

Mouse strain and exposure
B

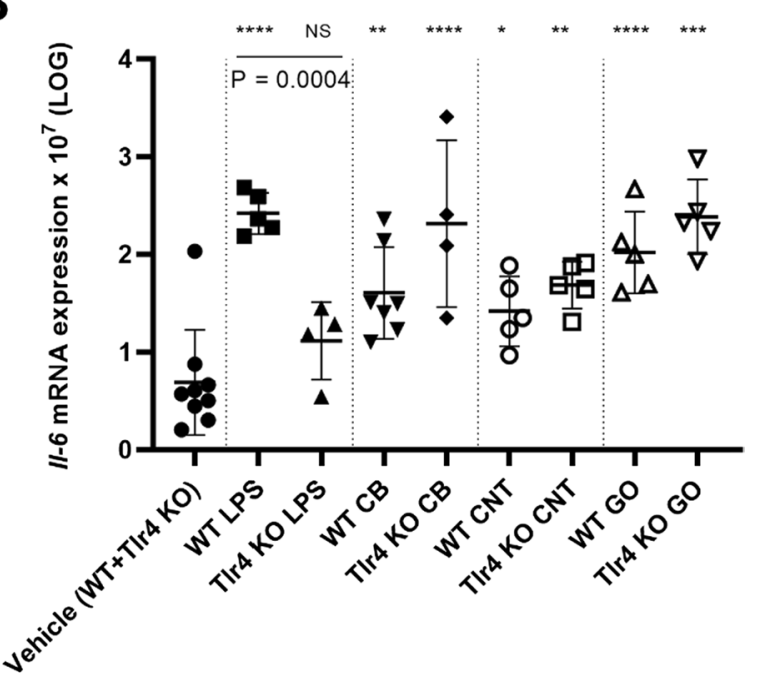

Mouse strain and exposure

D

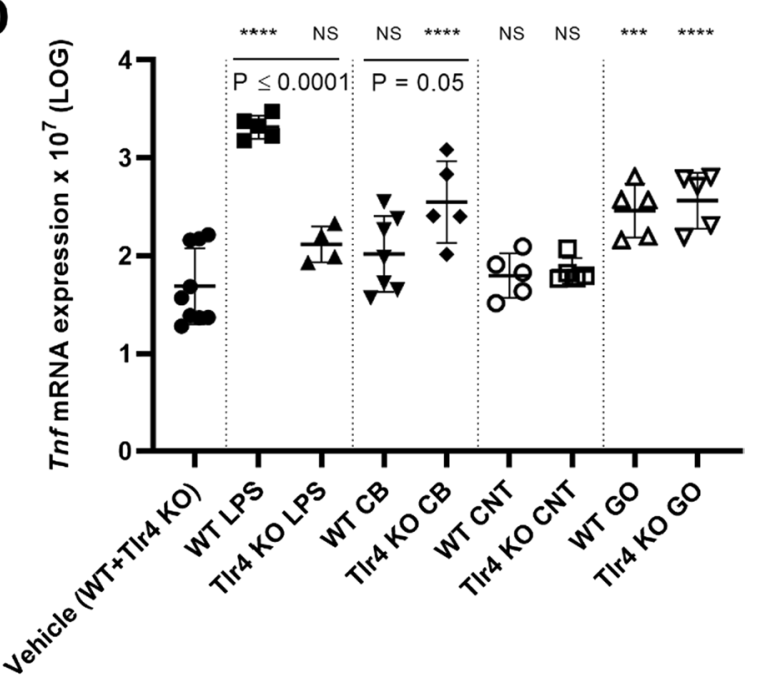

Mouse strain and exposure

Fig. 2 Pulmonary mRNA expression levels of II-6 in T/r2 KO mice versus WT mice (A) and T/r4 KO mice versus WT mice (B). Pulmonary mRNA expression levels of $\operatorname{Tnf}$ in T/r2 KO mice versus WT mice (C) and T/r4 KO mice versus WT mice (D). All values are log transformed and presented as mean \pm SD. A marker $\left(^{*}\right)$ denotes $P \leq 0.05,\left(^{* *}\right) P \leq 0.01,\left(^{* *}\right) P \leq 0.001,\left(^{* * *}\right) P \leq 0.0001$ compared to vehicle control (Dunn's multiple comparison method). The vertical lines mark statistically significant differences between $\mathrm{KO}$ mice and WT mice (unpaired t-test)

Saa3 expression levels correlated strongly $(\mathrm{r}=0.7909$, $\mathrm{P}<0.0001)$ with neutrophil influx across exposures and mouse strains (Additional file 1: Fig. S7A) as previously reported for different NMs where pulmonary acute phase response is induced in parallel with the pulmonary inflammatory response [29, 32, 33, 46-50]. Correlations between Tnf and Saa3, and Il-6 and Saa3 were similarly highly significant $(\mathrm{r}=0.8321, \mathrm{P}<0.0001$ and $\mathrm{r}=0.7962$, $\mathrm{P}<0.0001$ ) (Additional file 1: Fig. S8). Furthermore, Lcn2 and Saa1 mRNA levels in lung tissue, characterized the pulmonary acute phase response, and showed similarly strong correlation with neutrophil influx (Additional file 1: Fig. S7B, S7C). The expression levels of Lcn2 and Saa1 were generally much lower in the lung than in liver. However, lung Saa1 and Lcn2 expression levels were unaffected by TLR2 status (Figs. 6C, 8C), whereas CNTand GO-induced Saa1 and Lcn2 expression showed a TLR4-dependent pattern (Figs. 6D and 8D). 


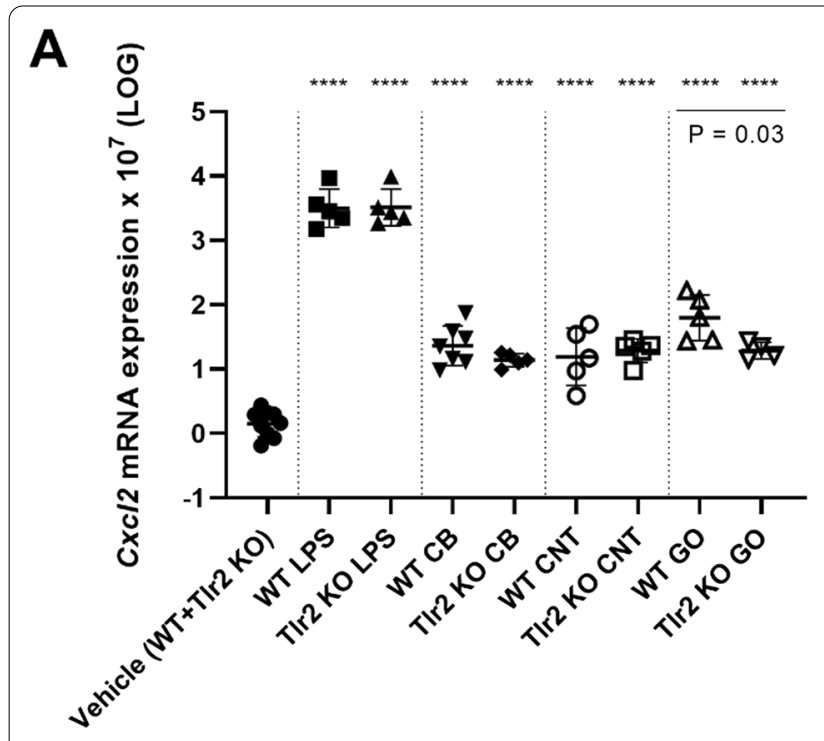

Mouse strain and exposure

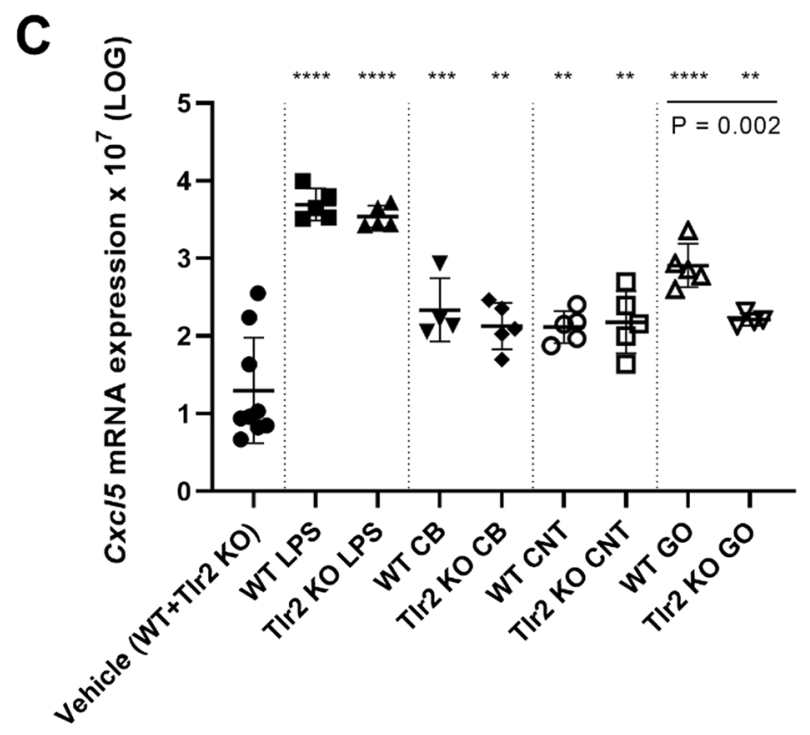

Mouse strain and exposure

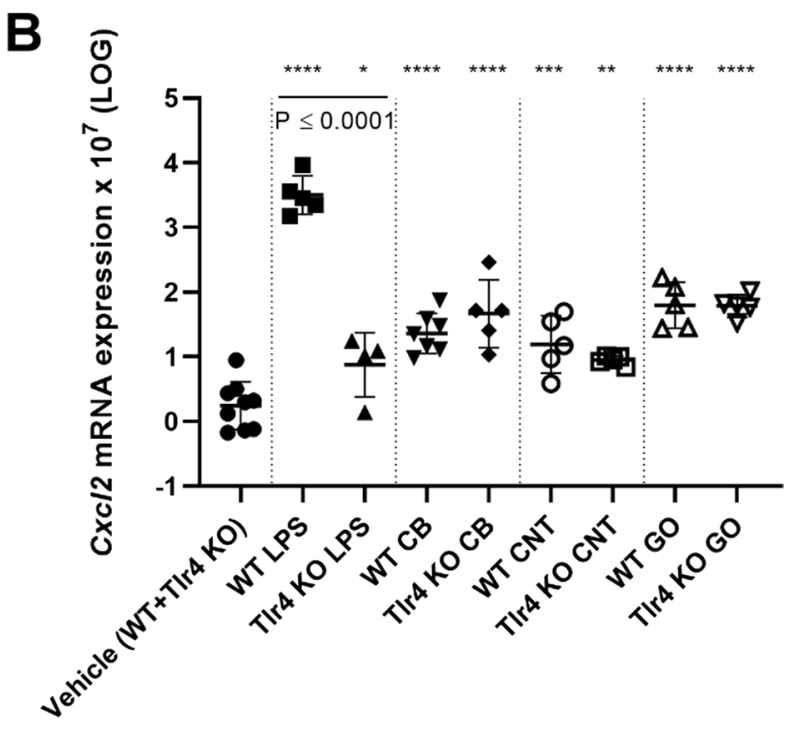

Mouse strain and exposure

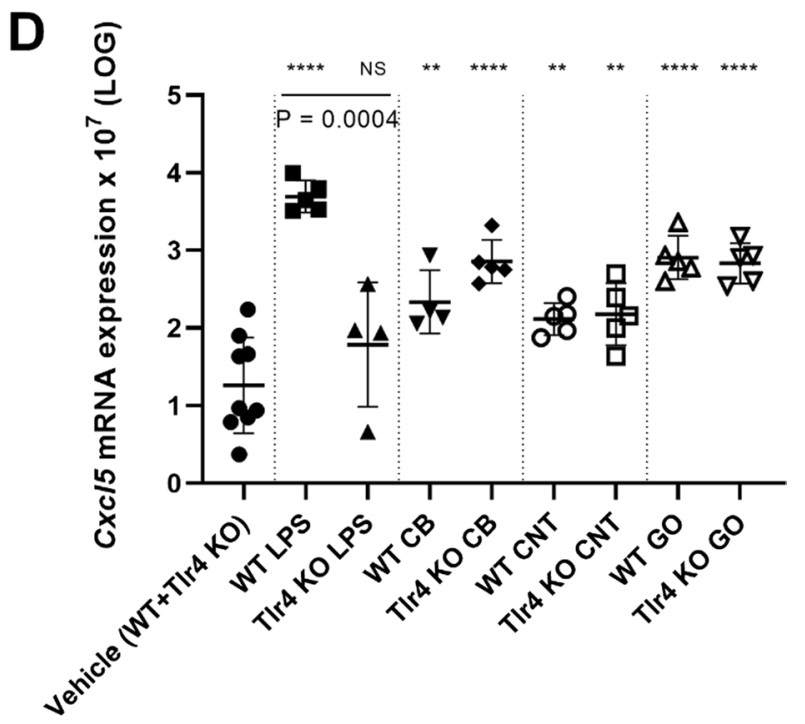

Mouse strain and exposure

Fig. 3 Pulmonary mRNA expression levels of $C x \mathrm{Cl} 2$ in T/r2 KO mice versus WT mice (A) and T/r4 KO mice versus WT mice (B). Pulmonary mRNA expression levels of $C x C 15$ in T/r2 KO mice versus WT mice (C) and T/r4 KO mice versus WT mice (D). All values are log transformed and presented as mean \pm SD. A marker $\left(^{*}\right)$ denotes $P \leq 0.05,\left(^{* *}\right) P \leq 0.01,\left(^{* *}\right) P \leq 0.001,\left(^{* * *}\right) P \leq 0.0001$ compared to vehicle control (Dunn's multiple comparison method). The vertical lines mark statistically significant differences between $\mathrm{KO}$ mice and WT mice (unpaired t-test)

Pulmonary Saa3 expression has been shown to be paralleled by increased plasma levels of SAA3 protein in mice exposed to CNT, CB and GO [29, 34, 35], thereby propagating the pulmonary response to a systemic level. In the present study, increased systemic SAA3 protein levels in plasma were confirmed following exposure to LPS and GO (Fig. 5). As expected, LPS-induced plasma levels of SAA3 were significantly lowered in Tlr4 $\mathrm{KO}$ mice, whereas GO-induced SAA3 protein levels were unaffected by TLR status, which is in contrast to the pulmonary response.

\section{Hepatic acute phase response}

Hepatic acute phase response was assessed by the measurement of Saa1 [32, 34, 51, 52] and Lcn2 mRNA expression levels $[29,31]$. The liver is the major site for SAA1 production induced by inflammation, trauma or stress [53]. The acute phase protein LCN2, which is the 


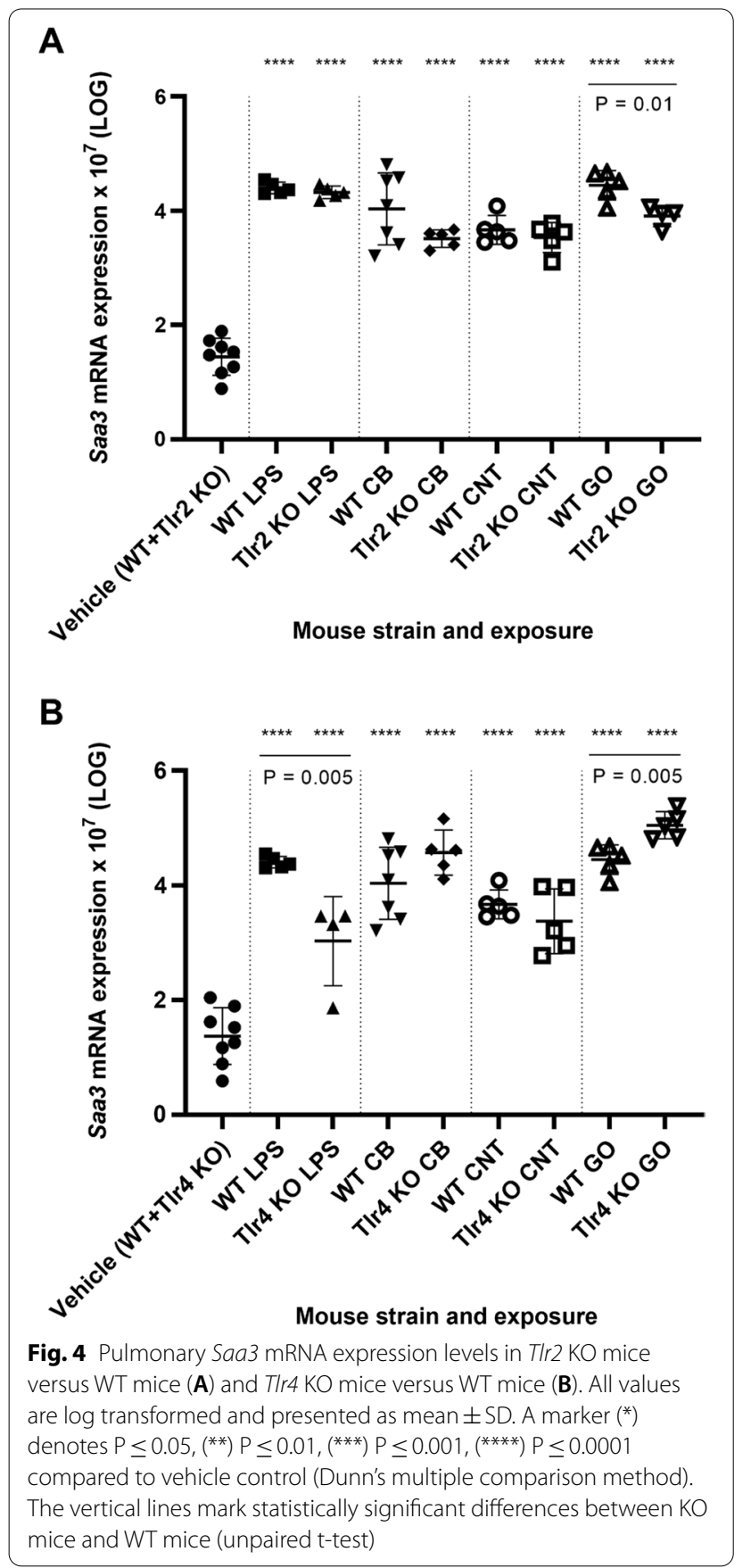

mouse homolog of human neutrophil gelatinase associated lipocalin (NGAL) has been shown to be expressed in various tissues promoted by TLR 4 and inflammatory cytokines (reviewed in [54]). Lcn2 is one of the most differentially expressed genes in mouse liver 1 day after instillation with CB [29].

Overall, Saa1 gene expression in the liver (Fig. 6A, B) was significantly increased for most NMs and mouse strains compared to the vehicle control. As expected,

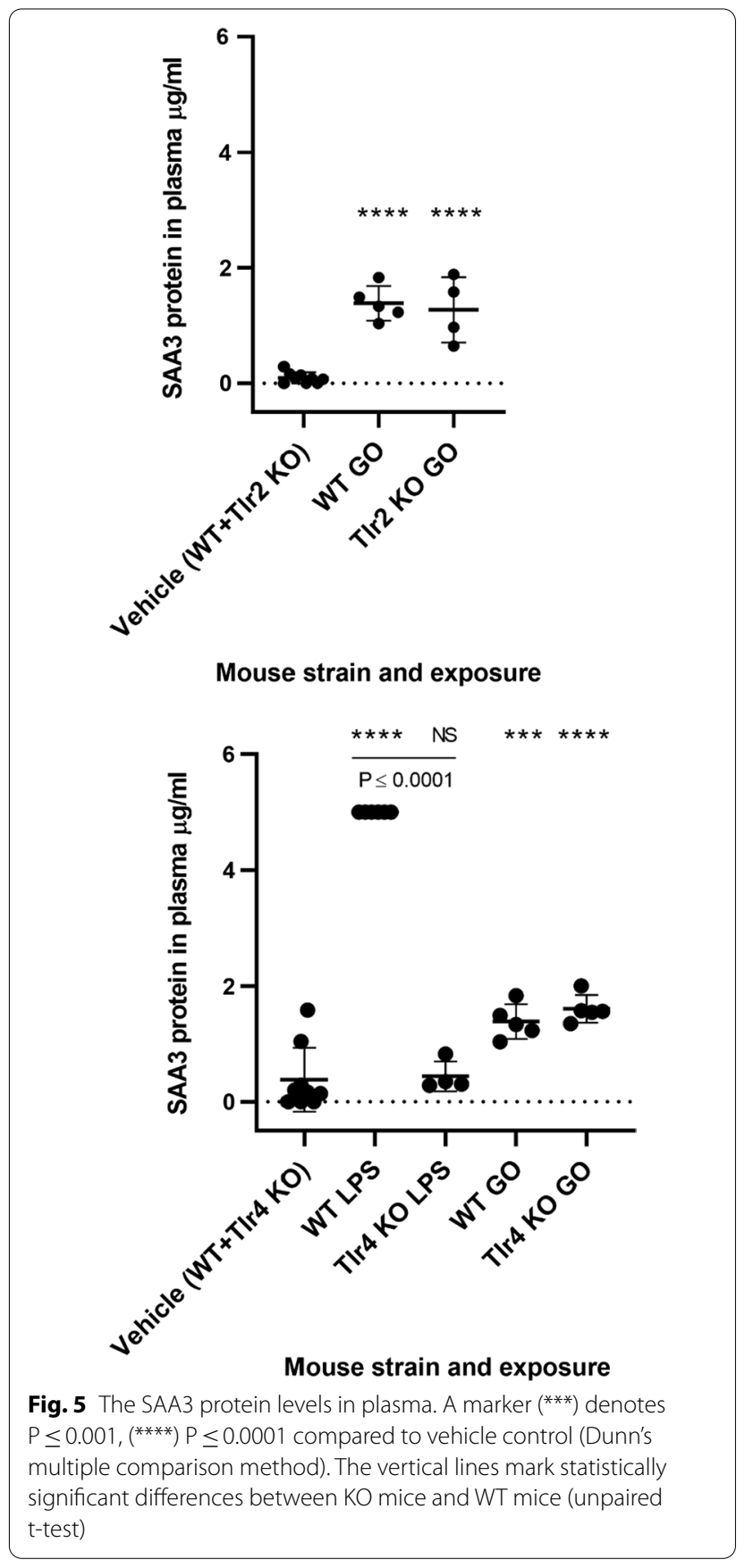

when exposed to LPS, the level of Saa1 mRNA was significantly decreased for the Tlr4 $\mathrm{KO}$ mice compared to WT mice ( $<<0.01)$, whereas LPS-induced hepatic Saa1 expression was again unaffected by TLR2 status. Furthermore, Saa1 mRNA levels were statistically significantly lowered in liver of mice exposed to $\mathrm{CB}(\mathrm{P}<0.01$, Tlr2 KO mice), CNT ( $<<0.05$, both Tlr2 and Tlr4 KO mice) and GO ( $\mathrm{P}<0.01, T l r 2 \mathrm{KO}$ mice $)$ compared to WT mice. 


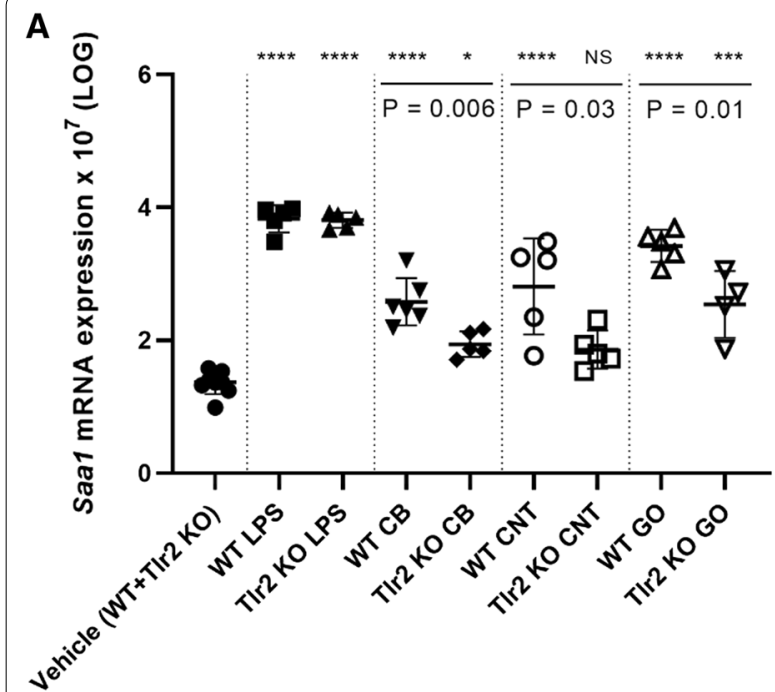

Mouse strain and exposure

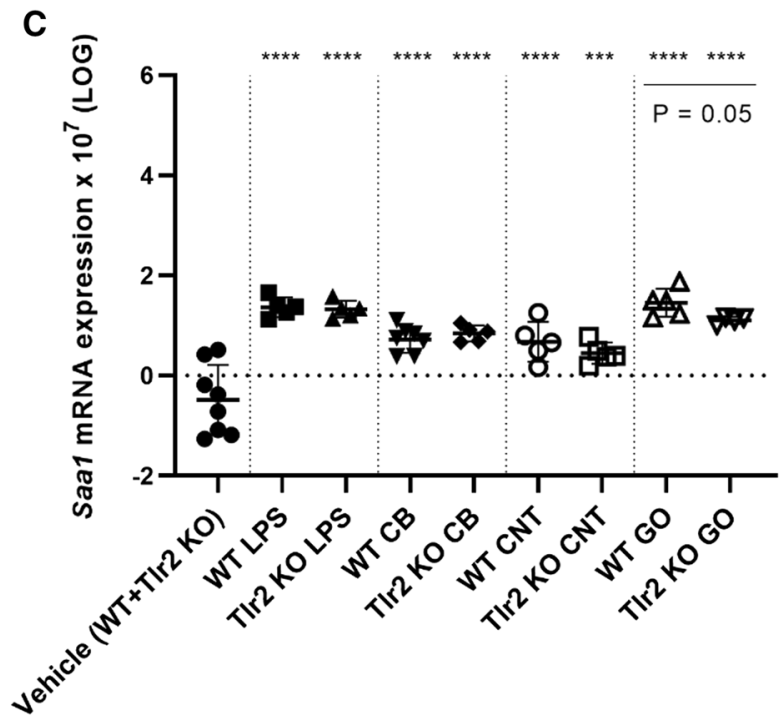

Mouse strain and exposure

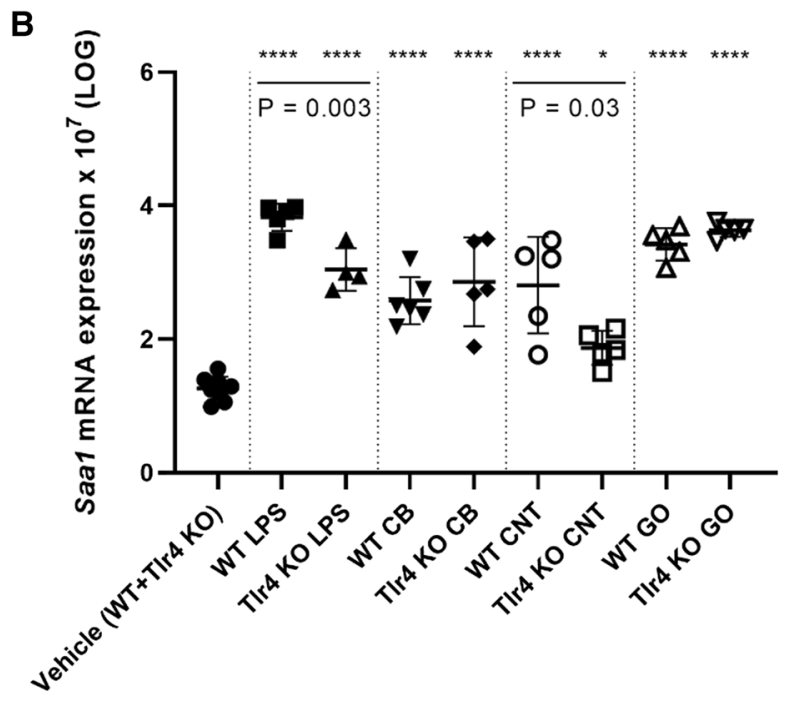

Mouse strain and exposure

D

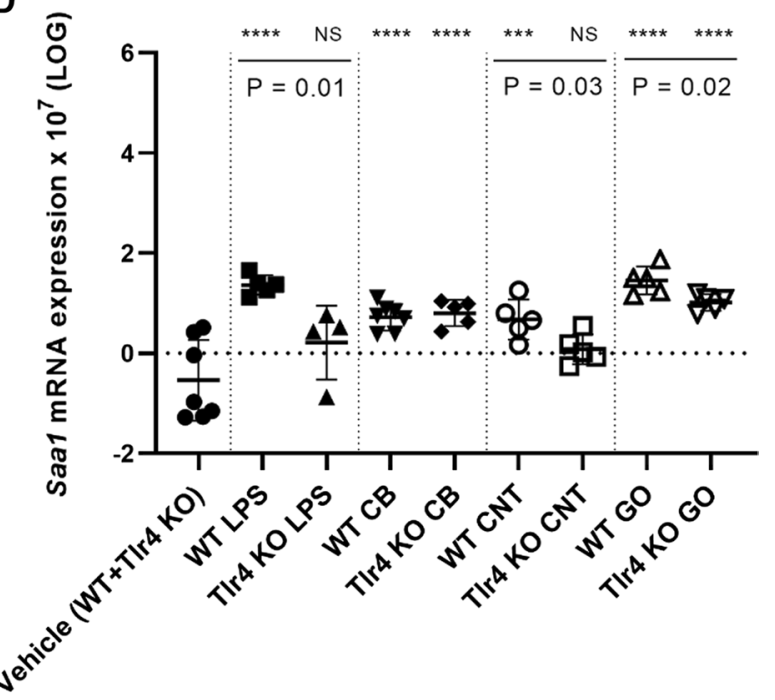

Mouse strain and exposure

Fig. 6 Hepatic mRNA expression levels of Saa 1 in T/r2 KO mice versus WT mice (A) and T/r4 KO mice versus WT mice (B). Pulmonary mRNA expression levels of Saa 1 in T/r2 KO mice versus WT mice $(\mathbf{C})$ and T/r4 KO mice versus WT mice (D). All values are log transformed and presented as mean \pm SD. A marker $\left(^{*}\right)$ denotes $P \leq 0.05,\left(^{* *}\right) P \leq 0.01,\left(^{* *}\right) P \leq 0.001,\left({ }^{* * *}\right) P \leq 0.0001$ compared to vehicle control (Dunn's multiple comparison method). The vertical lines mark statistically significant differences between KO mice and WT mice (unpaired t-test)

The lowered hepatic Saa1 mRNA levels were reflected in the SAA1/2 protein levels from CB-exposed Tlr2 $\mathrm{KO}$ mice $(\mathrm{P}=0.004)$ and $\mathrm{CNT}$-exposed Tlr2 and Tlr4 $\mathrm{KO}$ mice $(\mathrm{P}=0.001$ and $\mathrm{P}=0.0025$, respectively) (Fig. 7$)$. This match was not observed for $L c n 2$ mRNA levels in liver, as only Tlr4 KO, but not Tlr2 KO mice showed a CNT exposure related response.

The decreased hepatic Saa1 mRNA levels were similar to the pattern seen for hepatic NM-induced $L c n 2$ mRNA expression (Fig. 8A, B), which also seemed to be TLR2dependent. The expression pattern of hepatic Lcn2 and Saa1 correlated closely across exposures and $\mathrm{Tl} r$ status $(\mathrm{r}=0.9407, \mathrm{p}<0.0001)$ (Additional file 1: Fig. S9). Thus, hepatic Saa1 and Lcn2 expression was dependent on TLR2 for CB, CNT and GO, whereas LPS-induced hepatic Saa 1 and $L c n 2$ expression was TLR4-dependent.

The pulmonary levels of Saa1 and Lcn2 mRNA (Figs. 6C, D, 8C, D) were related to the hepatic 


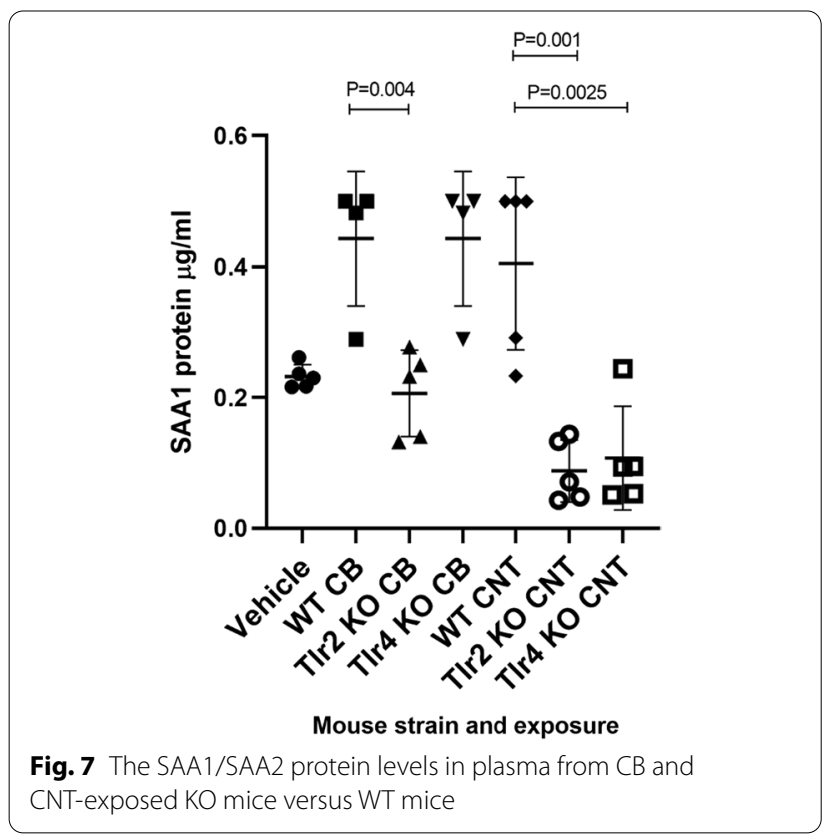

expression of the same genes to assess the possible role of these in the signaling from lung to liver. However, whereas NM-induced hepatic Saa1 and Lcn2 expression was TLR2-dependent, lung Saa1 and Lcn2 expression were unaffected by TLR2 status, suggesting that the here investigated pulmonary acute phase response genes do not have a strong role in mediating the hepatic acute phase response.

All results are compiled in overview Table 4.

\section{Discussion}

The aim of the present study was to investigate the interaction between carbon-based NMs and the lung in relation to inflammatory signaling and acute phase response. In addition, we wanted to assess whether the Toll-like receptors TLR2 and TLR4, two crucial cell surface receptors of the innate immune system, are required to initiate the pulmonary and systemic inflammatory response to pulmonary deposited, carbon-based NMs. We used three different NMs, CB, CNT and GO to elucidate the impact of shape and compared the inflammatory responses with that of the well-characterized LPS, which is known to be mediated by TLR4. To this end, we assessed pulmonary inflammation and acute phase response in the lung as well in the liver of Tlr2 and Tlr4 $\mathrm{KO}$ mice exposed to NMs and LPS as a positive control. The effects were compared to observations in WT mice with the same genetic background.

Optimally, we would have included more doses and time points, but due to costs and limited availability of the Tlr4 KO-model from the supplier, we had to limit the study design to a single dose and time point in order to be able to include three different NMs. However, we have previously shown that the acute phase response in the liver is present at $24 \mathrm{~h}$ post-exposure, but not at later time points even for MWCNT [33]. As for the pulmonary response, we believe that the $24 \mathrm{~h}$ time point is the most well characterized acute time point in terms of neutrophil influx and gene expression [29, 33-36, 55, 56].

Due to improvement of statistical power and due to the differences in group-sizes, we chose to combine the vehicle-exposed controls for WT mice and Tlr2 KO mice in the analysis of TLR2-related effects, and WT mice and Tlr4 KO mice in the analysis of TLR4-related effects. There were no statistically significant differences between the control groups for any outcome. However, the comparison of the endpoints across mouse strains were independent of the vehicle-exposed control groups.

As expected, Tlr4 $\mathrm{KO}$ mice exposed to LPS generally showed a reduced inflammatory response indicated by a $70 \%$ reduction of neutrophil influx. Compared to WT mice, LPS-exposed Tlr2 KO mice showed reduced levels only for lung Lcn2 gene expression. Moreover, LPSexposed Tlr4 $\mathrm{KO}$ mice did not show any pulmonary cytokine/chemokine responses (Il-6, Tnf, Cxcl2, Cxcl5 mRNA) and no increase of systemic SAA3 protein levels in plasma. However, for other genes, such as $\mathrm{Saa} 3$ in the lungs and Saa1 mRNA in the liver, the LPS-response in Tlr4 KO mice remained significantly increased over the vehicle control, yet still lower than the corresponding WT mice, suggesting that TLR4-independent mechanisms, such as via TLR2, may partly regulate their LPSsensitive gene expression.

The neutrophil influx has been shown to peak for LPSand $\mathrm{CB}$-induced inflammation around $12-24 \mathrm{~h}$ after exposure and declines rapidly over time [45, 57]. For practical experimental reasons, $24 \mathrm{~h}$ was preferred as the single time point for the investigation of the acute inflammatory response, even though we have previously shown that CNT- and GO-induced pulmonary inflammation rises over time and is higher 3 days post-exposure [34, 35]. The selected dose levels aimed to reach similar levels of roughly 100.000 neutrophils (total recovered cells per lung) in WT mice when exposed to $162 \mu \mathrm{g} \mathrm{CB}, 54 \mu \mathrm{g}$ $\mathrm{CNT}$, and $18 \mu \mathrm{g} \mathrm{GO}$. The factual levels of neutrophils differed slightly with neutrophil mean levels about 132.000 for $\mathrm{CB}, 71.000$ for $\mathrm{CNT}$ and 218.000 for GO, but this had no practical impact as the differences between type of exposure are not directly compared in the study. The dose levels are representative for the potential human exposure in occupational settings. Based on the current Danish occupational exposure limit of $3.5 \mathrm{mg} / \mathrm{m}^{3}$ and the lung deposition reported as lung burden in mice by Heinrich et al. [58], a dose level of $162 \mu \mathrm{g} /$ mouse CB would 


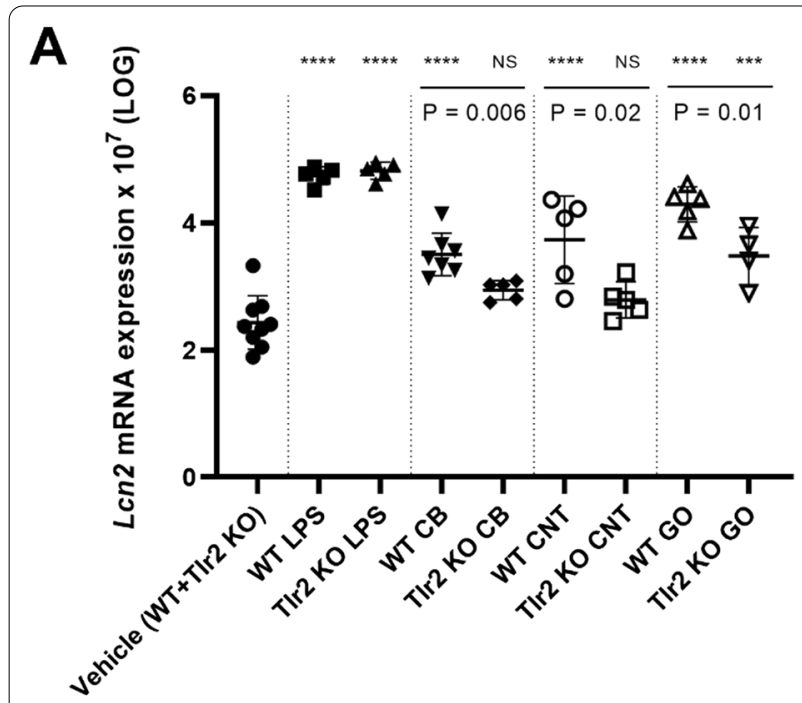

Mouse strain and exposure

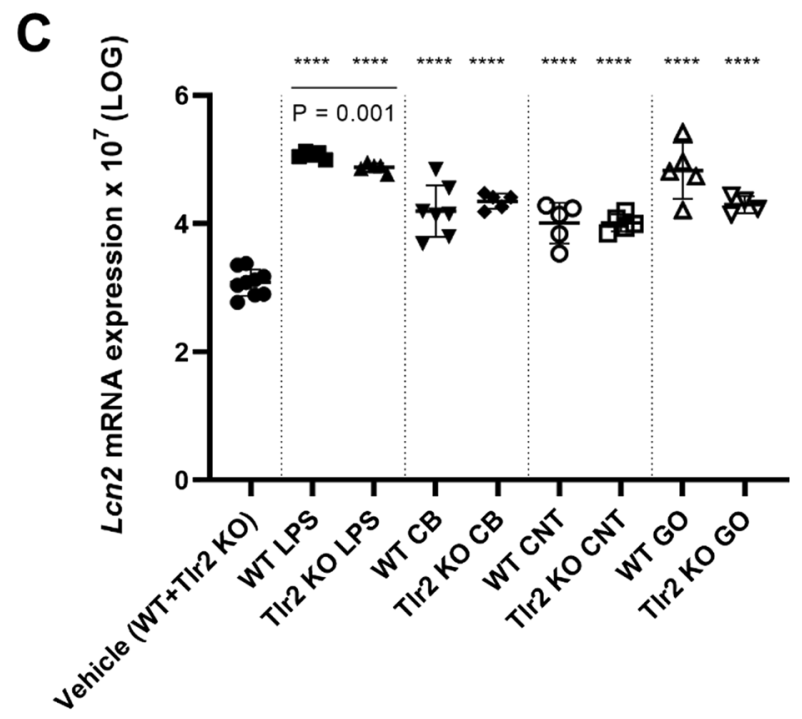

Mouse strain and exposure

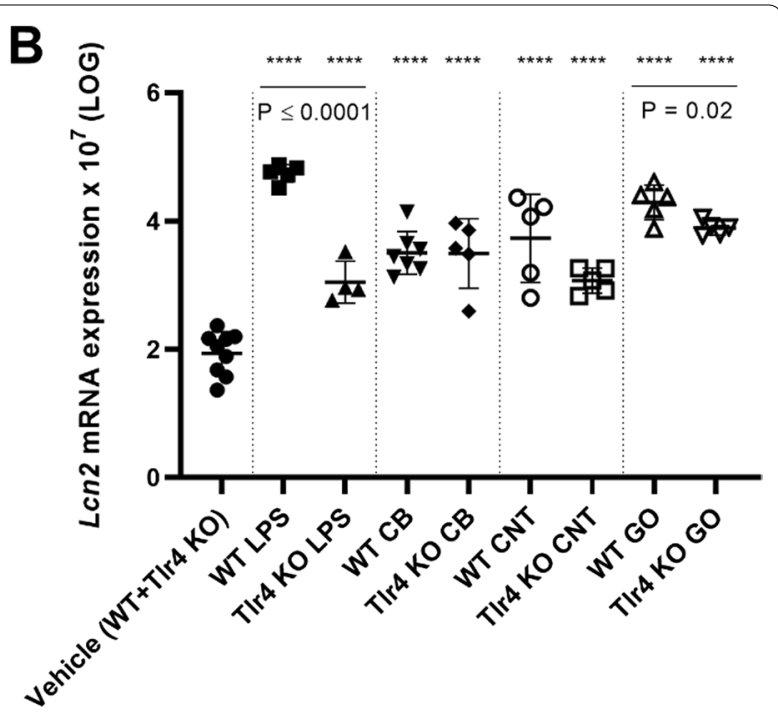

Mouse strain and exposure

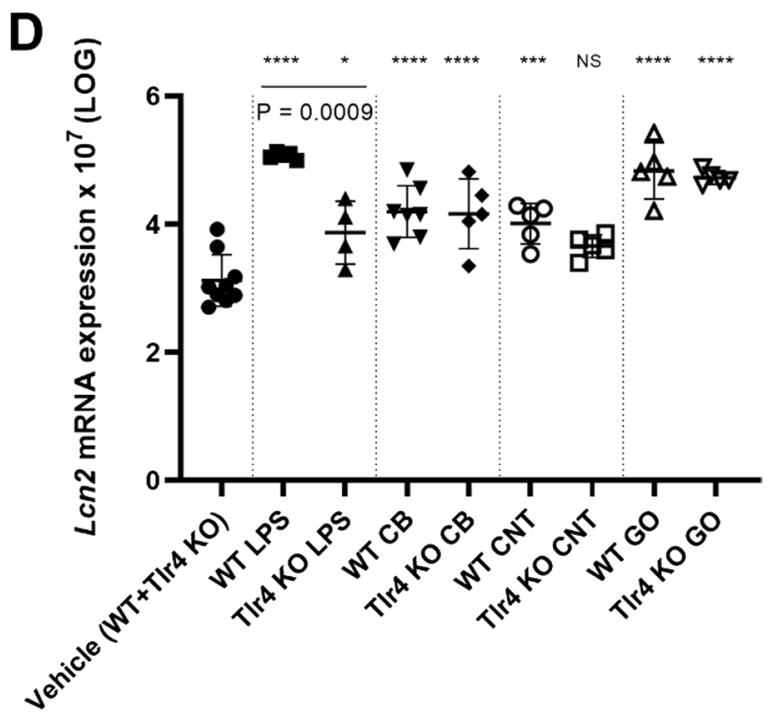

Mouse strain and exposure

Fig. 8 Hepatic mRNA expression levels of Lcn2 in T/r2 KO mice versus WT mice (A) and T/r4 KO mice versus WT mice (B). Pulmonary mRNA expression levels of $L c n 2$ in T/r2 KO mice versus WT mice $(\mathbf{C})$ and T/r $4 \mathrm{KO}$ mice versus WT mice (D). All values are log transformed and presented as mean \pm SD. A marker $\left(^{*}\right)$ denotes $P \leq 0.05,\left(^{* *}\right) P \leq 0.01,\left({ }^{* *}\right) P \leq 0.001,\left(^{* * *}\right) P \leq 0.0001$ compared to vehicle control (Dunn's multiple comparison method). The vertical lines mark statistically significant differences between KO mice and WT mice (unpaired t-test)

correspond to the retained lung burden after 3 months of occupational exposure to CB. Noteworthy, much higher occupational exposure levels $\left(14.9 \mathrm{mg} / \mathrm{m}^{3}\right)$ have been reported [59]. There are currently no occupational exposure limit for CNTs and GO.

Although, the measurement of mRNA expression does not necessary parallel the production of bioactive proteins, we consider qRT-PCR a reliably method and thus interpret increased mRNA expression to represent increased protein expression. Previous publications demonstrated that plasma SAA3 $[25,32,33]$ and SAA1 [33] protein levels correlated with mRNA expression in lung tissue of CNT-exposed mice. Following pulmonary CB exposure, we have previously reported dose-dependent increased protein levels of the following cytokines: IL1 $\beta$, IL2, IL3, IL5, IL6, IL9, IL10, IL12B, IL13, IL17, CCL2, CC14, CXCL1, CXCL2, INFG and TNF on lung tissue [60]. Occupationally CB-exposed workers had elevated 
Table 4 Overview of all results

\begin{tabular}{|c|c|c|c|c|c|c|c|c|c|c|c|c|c|}
\hline \multirow{2}{*}{\multicolumn{2}{|c|}{\begin{tabular}{|c|} 
Treatment \\
Genotype
\end{tabular}}} & \multicolumn{3}{|c|}{ LPS } & \multicolumn{3}{|c|}{ CB } & \multicolumn{3}{|c|}{ CNT } & \multicolumn{3}{|c|}{ GO } \\
\hline & & \multirow{2}{*}{$\begin{array}{l}\text { WT } \\
++\end{array}$} & \multirow{2}{*}{$\frac{T l r 2 \mathrm{KO}}{+}$} & \multirow{2}{*}{$\begin{array}{c}\text { Tlr4 KO } \\
0\end{array}$} & \multirow{2}{*}{$\frac{\text { WT }}{++}$} & \multirow{2}{*}{$\frac{\text { Tlr2 KO }}{++}$} & \multirow{2}{*}{$\frac{\text { Tlr4 KO }}{++}$} & \multirow{2}{*}{$\frac{\text { WT }}{++}$} & \multirow{2}{*}{$\frac{\text { Tlr2 KO }}{++}$} & \multirow{2}{*}{$\begin{array}{c}\text { Tlr4 KO } \\
+\end{array}$} & \multirow{2}{*}{$\frac{\text { WT }}{++}$} & \multirow{2}{*}{$\frac{\text { Tlr2 KO }}{+}$} & \multirow{2}{*}{$\frac{T \operatorname{tr} 4 \mathrm{KO}}{++}$} \\
\hline BAL & Neutrophils & & & & & & & & & & & & \\
\hline \multirow{7}{*}{$\begin{array}{l}\text { Lung } \\
\text { genes }\end{array}$} & Il-6 & ++ & ++ & 0 & + & 0 & + & + & ++ & + & ++ & ++ & ++ \\
\hline & Cxcl2 & ++ & ++ & 0 & + & + & + & + & + & + & ++ & + & ++ \\
\hline & Cxcl5 & ++ & ++ & 0 & + & + & + & + & + & + & ++ & + & ++ \\
\hline & Len 2 & ++ & + & 0 & + & + & + & + & + & 0 & + & + & + \\
\hline & Saa1 & ++ & ++ & 0 & + & + & + & + & + & 0 & ++ & + & + \\
\hline & Saa 3 & ++ & ++ & + & ++ & ++ & ++ & ++ & ++ & ++ & ++ & + & ++ \\
\hline & Tnf & ++ & ++ & 0 & 0 & 0 & + & 0 & 0 & 0 & + & 0 & + \\
\hline Plasma & SAA3 & ++ & ND & 0 & ND & ND & ND & ND & ND & ND & ++ & ++ & ++ \\
\hline Plasma & SAA1/2 & ND & ND & $\mathrm{ND}$ & + & 0 & + & + & 0 & 0 & ND & ND & ND \\
\hline \multirow{2}{*}{$\begin{array}{l}\text { Liver } \\
\text { genes }\end{array}$} & Saa1 & ++ & ++ & + & ++ & 0 & ++ & ++ & 0 & 0 & ++ & + & ++ \\
\hline & Len2 & ++ & ++ & 0 & + & 0 & + & + & 0 & + & + & 0 & + \\
\hline
\end{tabular}

The markings $(0,+,++)$ relates to the responses comparing the NM-exposed mice to the corresponding vehicle-exposed, where 0 designates no effect, + indicates statistically significant changes and ++ indicates strong statistically significant changes compared to the corresponding vehicle-exposed group

The green marking indicates a statistically significantly lower response in KO mice compared to WT mice

The blue marking indicates a statistically significantly higher response in KO mice compared to WT mice

$N D$ not determined

blood levels of IL1 $\beta$, IL6, IL8, MIP1 $\beta$ and TNF [59]. Thus, the CB-induced pulmonary gene expression pattern fits well with previously reported blood levels of cytokines in mice and humans.

We have consistently found that pulmonary exposure to NMs by inhalation or by instillation induces a pulmonary acute phase response characterized by induced levels of SAA3 [20]. SAA are pleotropic proteins that also function as monocyte- and granulocyte chemoattractants [61] and the Saa3 mRNA levels in lung tissue correlates with the number of neutrophils in BAL fluid in several in vivo studies $[25,33,47,48,50,51]$. In the present study, the pulmonary gene expression of Saa1, Saa3 and $L c n 2$, which are all among the top 10 ranked acute phase response genes in lung tissue of mice after exposure to various NMs by i.t. instillation [20], correlate with neutrophil levels.

Here, we provide evidence that the NM-induced inflammatory and acute phase response differ from the LPS-mediated response. LPS exposure at moderate levels, not provoking significant tissue injury, caused a strong induction of pro-inflammatory cytokines $\mathrm{Il}-6$ and $\operatorname{Tn} f$ mRNA levels, which were almost reduced to control levels in Tlr4 $\mathrm{KO}$ mice. This pattern were paralleled by lowered expression levels of Saa3, Saa1, Lcn2, Cxcl2, $\mathrm{Cxcl5}$ and a numerically lowered neutrophil influx in
LPS-exposed Tlr4 KO mice. In addition, systemic, serum SAA3 and hepatic acute phase response in terms of Saa1 and $L c n 2$ expression levels was also absent in Tlr4 $\mathrm{KO}$ mice after LPS exposure.

CB-mediated pulmonary inflammation was virtually unaffected by TLR2 and TLR4 status, although a tendency of decreased Il-6 and Tnf expression was observed in Tlr2 KO mice. CB caused comparable neutrophil levels in all mouse strains, indicating no essential contribution of TLR2 or TLR4 signaling to the acute inflammatory response. Overall, the results suggest that $\mathrm{CB}$-mediated pulmonary inflammation is independent of TLR2 and TLR4.

CNT-mediated pulmonary inflammation was most affected in Tlr4 $\mathrm{KO}$ mice, in which the BAL neutrophil influx and macrophage cell numbers were diminished, compared to WT mice. Saa1 mRNA expression was reduced in Tlr4 $\mathrm{KO}$ mice exposed to CNT, but levels failed to show significant increases over vehicle controls. The latter may be seen in agreement with previous findings that $\mathrm{Saa} 1$ expression correlates closely with neutrophil influx following NM-exposure [20].

The neutrophil influx was 35\% decreased in GOexposed Tlr2 KO mice, although this was a non-significant observation, most of the analyzed lung markers Tnf, Saa3, Saa1, Lcn2, Cxcl2 and Cxcl5 were significantly 
decreased as compared to WT mice. Only the levels of Il-6 and Lcn2 mRNA in the lung and plasma SAA3 remained unaffected by the Tlr2 genotype in GOexposed mice. Overall, the results suggest an essential involvement of TLR2 in the response to GO. This may suggest a direct interaction between GO and TLR2, since the other NMs induce similar expression patterns for Saa1 and Saa3, which are known to interact directly with TLR2 $[18,62]$. The studied GO has a very low C/O ratio, suggesting a heavily hydroxylated surface [63]. This may have a structural resemblance to the polysaccharide part of LPS. In agreement with this, GO induces a very strong acute phase response following pulmonary exposure in mice as compared to reduced GO, which contains much less oxygen [35].

In summary, our data clearly demonstrate, that TLR2 or TLR4 signaling is not fully required for the initiation of the acute pulmonary inflammatory response. TLR2 contributed essentially to the response to GO exposure and TLR4 to that of CNTs. However, if these carbon structures may specifically bind to TLR2 and TLR4 complexes expressed on various lung cells, this interaction is not required to drive the NM-triggered pulmonary inflammation. However, the fiber-like structural resemblance between LPS [64] and the thick and straight CNT used in the current study could suggest that the CNT interacts directly with TLR4, as suggested by computational studies [26, 27]. The three carbon-based NMs differ by shape, but also by surface chemistry. The $\mathrm{CB}$ Printex 90 from Evonik/Degussa consists of more than 99 $\mathrm{wt} \%$ elemental carbon with traces of organic compounds (less than 1\%). We have previously reported that TEM analysis showed that Printex 90 in instillation suspension consisted of both free and open to partially open chainagglomerates and that high-resolution analysis showed that the spheres consisted of concentric layers with graphitic spacing, resembling nano-onions structures [29]. The Mitsui-7 CNT has a low oxygen content [65] and therefore presumably a hexagonal lattice structure on the surface, whereas the GO used in this study has a very low $\mathrm{C} / \mathrm{O}$ ratio suggesting a highly hydroxylated surface as compared to the unmodified CNT [63]. It is possible that both shape and surface chemistry are important determinants for the molecular interaction with PRRs.

The observed differences in the contribution of TLR2 or TLR4 signaling to the inflammatory response could also reflect that the different NMs interact with different cell types in the lungs, or TLR-ligands, such as DAMPs released from the CNT- or GO-exposed cells enhance the elicited inflammation. We have recently shown that LPS and $\mathrm{CB}$ exposure induces Saa3 expression in different cell types in the lungs of mice using single cell sequencing [22]. Thus, LPS-exposure induced Saa3 expression predominantly in non-classical monocytes, whereas $\mathrm{CB}$ induced Saa3 expression in mesenchymal cells [22]. We previously also provided evidence, that in contrast to LPS, CB exposure rather stimulates lung epithelial cells, whereas resident lung macrophages remain quite quiescent [45]. Our current data again support the notion that pulmonary inflammation signaling differs substantially between LPS and the here tested NMs, and between the different NMs.

Most interestingly, we observed the strongest TLR involvement in the induction of hepatic acute phase response characterized by hepatic $S a a 1$ and $L c n 2$ expression after pulmonary NM-exposure. The observed NM-dependent hepatic acute phase response is in concordance with previous findings for the same or analogue materials [29, 32, 35, 36], as well as for other CNTs. NM translocation from lung to liver has been demonstrated for CB [66], MWCNT [67, 68] and few layer graphene [69]. NMs accumulate primarily in Kupffer cells in the liver [70]. Histopathological examination of the liver has been included in several studies. The MWCNT NM-401, with similar physicochemical properties as Mitsui-7, was shown to induce histopathological changes in the liver 1 day post-exposure, with an increase in lesion frequency 3 and 28 days post-exposure [32]. These changes included vacuolar degeneration, granulomas, necrosis of hepatocytes, and increased number and/or hypertrophy of Kupffer cells, all indicative of inflammation and general hepatic pathology. Similar hepatic histological changes were observed after pulmonary exposure to nano-sized $\mathrm{CB}$ and nanosized $\mathrm{TiO}_{2}$ [56]. The observed LPS-mediated hepatic response was dependent on TLR4 and independent of TLR2, as was the level of pulmonary inflammation. LPS-induced liver inflammation has been shown to depend on TLR4 when comparing WT and TLR4-/- mice exposed to LPS and similar responses were provoked in primary hepatic Kupffer cells isolated from the mice following LPS exposure [71]. This suggests that the TLR4-dependent liver inflammation was initiated by a direct interaction between LPS and Kupffer cells. It is possible, that translocated MWCNT also interacts directly with TLR4 on Kupffer cells. Similarly, it is possible that the three different NMs interact directly with TLR2 on Kupffer cells following translocation, and that this forms the basis of the observed differences in TLR-dependency of the hepatic acute phase response.

\section{Conclusions}

In conclusion, the involvement and requirement of TLR2 or TLR4 signaling for lung inflammation and lung and liver acute phase response differed between the three studied NMs, indicating that shape and surface chemistry may be determinants of the pathways triggered even 
at comparable levels of pulmonary inflammation. Particularly, these differences led to significant differences in the downstream systemic signaling as indicated by the observed differences in TLR2- and TLR4-dependency of the expression of hepatic acute phase response genes. In the lung, the GO-induced inflammation was to a considerable degree dependent on TLR2, and MWCNTinduced inflammation was partly TLR4-dependent. From this data, it could be suggested, that TLR2 is either involved in the pulmonary sensing of the dosed GO, and TLR4 in the sensing of the specific MWCNTs (Mitsui-7), or that NM specific injury pattern cause a specific release of DAMPs, functioning as TLR2 or TLR4 ligands, respectively. However, even though a direct NM-TLR interaction could not be studied here, our data clearly show that the innate immune response receptors TLR2 nor TLR4 are not requisite for the acute lung toxicity of $\mathrm{CB}$, but contribute to that of the specific GO and CNT investigated here. TLR2 was required for the induction of acute phase response in the liver for all three NMs, whereas LPS-dependent signaling to the liver was entirely TLR4dependent. The TLR4-dependent response in liver has been shown to depend on direct interaction between Kupffer cells and LPS. TLR4 was also required for induction of MWCNT-induced Saal gene expression in the liver, but not for liver Saa1 expression triggered by $\mathrm{CB}$ or GO exposure. The difference in TLR-dependency may suggest that the liver response were induced by direct interaction with translocated NMs, but this warrants further investigation.

\section{Methods}

\section{Nanomaterials and positive control}

The NMs included CB, multi-walled CNT and GO. The CB (Printex 90) was a kind gift from Degussa-Hüls, Frankfurt, Germany. CB has been extensively studied, and used as a benchmark particle in previous in vivo studies [29, 30, 33, 47, 51, 55, 72]. The characterization of CB has been described in detail elsewhere [29, 73]. GO was delivered in a water suspension manufactured and supplied by Graphena (San Sebastian, Spain). A detailed description and characterization of GO has been published previously [63]. The CNT was the multi-walled Mitsui 7 was a kind gift from Hadoga Chemical industry, Japan (former Mitsui Company) and the characterization has also been published previously [65]. LPS was included as a positive control (Lipopolysaccharides from Escherichia Coli O55:B5, Sigma-Aldrich).

\section{Preparation of nanomaterials for exposure and characterization}

The NMs were suspended in $2 \% \mathrm{v} / \mathrm{v} \quad \mathrm{C} 57 \mathrm{BL} / 6$ mouse serum in Nanopure Diamond water at a final concentration of $3.24 \mathrm{mg} / \mathrm{ml}$ and probe sonicated on ice, for $16 \mathrm{~min}$ with $10 \%$ amplitude without pause, using a Branson Sonifier S-450D (Branson Ultrasonics Corp., Danbury, CT, USA) equipped with a disruptor horn (model number 101-147-037) as previously described [74]. For the vehicle control group, $2 \% \mathrm{v} / \mathrm{v}$ C57BL/6 mouse serum in Nanopure Diamond water was similarly sonicated.

The average hydrodynamic particle size of the NMs in instillation suspensions $(3.24 \mathrm{mg} / \mathrm{ml})$ were measured by Dynamic Light Scattering ((DLS); Malvern Nano Zetasizer equipment mounted with a $633 \mathrm{~nm}$ red laser)). The results were obtained from six repeated analyses of the same sample.

\section{Animal handling and exposure}

Seven-week-old female mice (Tlr2 KO mice, B6.129Tlr $2^{\text {tm1Kir }} / \mathrm{J}$, stock 004650), (Tlr4 KO mice, B6(Cg)Tlr4 ${ }^{\text {tm1.2Karp }} /$ J, stock 029015), and C57BL/6 J (wildtype (WT) mice, stock 000664) were purchased from The Jackson Laboratory (Bar Harbor, Maine, USA). The mice were randomized to polypropylene cages and had access to food (Altromin 1324, Christian Petersen, Denmark), water ad libitum and to Solid Drink ${ }^{\circledR}$ Standard Bio with hydrocolloids $>98 \%$ water during the first days after arrival. The housing conditions have been described in detail elsewhere [47]. At 8 weeks of age, the mice were anaesthetized and exposed to NMs, LPS or vehicle by single i.t. instillation as described [75]. The group sizes varied $(\mathrm{N}=4-7$ per group) due to the unexpected death of a few mice upon arrival, limited availability of $\mathrm{KO}$ mice and reordering of new mice to be included in the latter part of the experiment to counteract these difficulties. Following sonication of the exposure stock as described above, the NM suspensions were diluted to obtain final concentrations of $18 \mu \mathrm{g}$ GO, $54 \mu \mathrm{g}$ CNT and $162 \mu \mathrm{g}$ CB per $50 \mu \mathrm{l}$, which was the instillation volume per mouse, and sonicated again for 2 min prior instillation. LPS was diluted in sterile $0.9 \%$ sodium chloride to the final concentration of $4 \mu \mathrm{g}$ per $50 \mu \mathrm{l}$. The vehicle control mice received $50 \mu \mathrm{l}$ of Nanopure Diamond water added $2 \%$ v/v C57BL/6 mouse serum. The doses of the NMs were based on previous in vivo studies, where the influx of neutrophils reached levels around $100.000[35,37]$ and therefore the doses differed between the types of NM. The instillation procedure has been described in detail previously [73, 75]. All animal procedures followed the guidelines according to the EC Directive 86/609/EEC and the Danish law. The experiments were approved by the Danish "Animal Experiment Inspectorate" under the Danish Ministry of Justice (2015-15-0201-00465). 


\section{Collection of BAL cells, plasma and tissue}

Mice were anesthetized and necropsied 1 day postexposure. To obtain the bronchoalveolar (BAL) fluid the lungs were flushed twice with sterile $0.9 \%$ sodium chloride through the trachea. The BAL fluid was kept on ice until separation of fluid and cells by centrifugation at $400 \times g$ for $10 \mathrm{~min}$ at $4{ }^{\circ} \mathrm{C}$. Heart blood was withdrawn via intracardiac puncture and stabilized with $\mathrm{K}_{2}$ EDTA. It was then fractionated by centrifugation and plasma was collected and stored at $-80{ }^{\circ} \mathrm{C}$. Small pieces of lung and liver tissues were snap frozen in cryotubes in liquid nitrogen and stored at $-80^{\circ} \mathrm{C}$ until isolation of RNA for mRNA expression analysis.

\section{Differential counting of BAL cells}

BAL cell composition was determined as previously described [74]. In short, the separated BAL cells were resuspended in $100 \mu \mathrm{l}$ HAMF12 medium containing 10\% fetal bovine serum. $40 \mu \mathrm{l}$ of the cell suspension was mixed with $160 \mu \mathrm{l}$ medium containing 10\% dimethyl sulfoxide (DMSO). The total number of cells and of dead cells was determined from $20 \mu \mathrm{l}$ diluted cell suspension by NucleoCounter NC-200TM (Chemometec, Allerød, Denmark). $40 \mu \mathrm{l}$ of the cell suspension was collected on microscope slides by centrifugation at $60 \times g$ for $4 \mathrm{~min}$ and where after the cells were fixed with $96 \%$ ethanol and stained with May-Grünwald-Giemsa. The samples were randomized and blinded before scoring of macrophages, neutrophils, lymphocytes, eosinophils, and epithelial cells, which were assessed by counting 200 cells/sample under light microscope $(100 \times$ magnification).

\section{Measurement of mRNA expression levels}

Gene expression levels was measured by quantitative real-time reverse transcriptase polymerase chain reaction (RT-PCR) as previously described [76]. In short, the acute phase response was assessed by the measurement of Saa3, Saa1 and lipocalin 2 (Lcn2) mRNA expression levels in lung and/or liver tissue. Inflammation was assessed by the measurement of interleukin-6 (Il-6), tumor necrosis factor (Tnf), chemokine ligand 2 (Cxcl2) and chemokine ligand 5 (Cxcl5) mRNA expression levels in lung tissue. Total RNA was isolated using Maxwell ${ }^{\circledR} 16$ LEV simply RNA Tissue Kit (AS1280, Promega, USA) according to the manufacturer protocol. Complementary DNA (cDNA) was prepared using TaqMan ${ }^{\circledR}$ reverse transcription reagents (Applied Biosystems, USA) according to the manufacturer protocol. Total RNA and cDNA concentrations were measured on NanoDrop 2000c (ThermoFisher, USA). The gene expression levels was determined using predesigned TaqMan expression assays and 18S rRNA as endogenous control (Applied Biosystems, USA). The samples were run in triplicates using ViiA7 Real-Time PCR detector (Applied Biosystems, USA). Negative controls were included in each run of the analysis. The relative expression of the target gene was measured by the comparative $\mathrm{C}_{\mathrm{T}}$ method after thoroughly assay optimization and validation.

\section{Measurement of total protein in BAL fluid}

Total protein content in BAL fluid was measured by Pierce $^{\mathrm{TM}}$ BCA Protein Assay Kit (Thermo Scientific, USA) according to the manufactures protocol and has been described in detail by [55].

\section{Measurement of SAA3 protein in plasma}

The SAA3 protein levels were determined in plasma and carried out by sandwich ELISA in accordance with the manufacturer's instructions (Mouse Serum Amyloid A-3, Cat.\#EZMSAA3-12K, Millipore) and has been described in detail by [33]. Only Tlr2 $\mathrm{KO}$ mice exposed to vehicle and GO and Tlr4 KO mice exposed to vehicle, LPS and $\mathrm{GO}$ were analyzed due to the cost of the kits.

\section{Measurement of SAA $1 / 2$ protein in plasma}

Plasma levels of serum amyloid A1 and A2 (SAA1/2) protein were measured using the Tridelta PHASE ${ }^{\mathrm{TM}}$ Murine Serum Amyloid A ELISA Assay (BioRépair, Sinsheim, Germany) according to the manufacturer's instructions. Due to experimental failures, one ELISA plate was discarded. The remaining measurements included all samples from CB and CNT exposed mice as well as vehicle samples from three WT mice and two Tlr4 KO mice, which were consequently pooled in the statistical analysis.

\section{Statistical analysis}

Statistical analyses were performed using the software package Graph Pad Prism 7.02 (Graph Pad Software Inc., La Jolla, CA, USA). In the statistics, we combine the vehicle-exposed controls for WT mice $(\mathrm{n}=4)$ and Tlr2 KO mice $(\mathrm{n}=5)$ in the analysis of TLR2-effects, and vehicle-exposed WT mice $(\mathrm{n}=4)$ and Tlr4 $\mathrm{KO}$ mice in the analysis of TLR4-effects $(n=5)$. There were no statistically significant differences between the control groups for any outcome. All data are expressed as mean \pm standard deviation and were tested for normality using the Shapiro-Wilks test and for variance homogeneity using the Brown-Forsythe test. The BAL cell count data did not fulfill normality and variance homogeneity criteria and the data were analyzed by the nonparametric KruskalWallis test to test the differences between the exposure groups and the vehicle, and the Mann-Whitney test to test the differences between WT and KO mice. Gene expression data were logarithmically transformed and analyzed by Dunnetts's multiple comparison method to 
test the differences between the exposure groups and the vehicle control group, and the unpaired $t$-test to test the differences between WT and KO mice. Total protein and the levels of SAA3 were analyzed by Dunnetts's multiple comparison method to test the differences between the exposure groups and the vehicle, and the unpaired t-test to test the differences between WT and KO mice. The SAA1/2 protein levels were analyzed by the nonparametric Kruskal-Wallis test to test the differences between the exposure groups and the vehicle, and the Mann-Whitney test to test the differences between WT and KO mice. P-values $\leq 0.05$ was considered significant. The Spearman rank correlation test was used to analyze the association between influx of neutrophils and acute phase response in lung tissue.

\section{Supplementary Information}

The online version contains supplementary material available at https://doi. org/10.1186/s12989-021-00432-z.

Additional file 1. Description of the pilot studies using Sparstolonin B.

\section{Acknowledgements}

The technical assistance from Michael Guldbrandsen, Eva Terrida, Dorte Larsen, Anne-Karin Asp, Anne Abildtrup, Yasmin Akhtar and Noor Irmam is gratefully acknowledged.

\section{Authors' contributions}

PHD, KMB, KBK, SSP and UV designed the study. PHD and KMB collected the in vivo data. PHD, KMB, TS and UV analyzed and interpreted the data. PHD drafted the manuscript. All authors contributed to the writing of the manuscript. All authors read and approved the final manuscript.

\section{Funding}

Funding for this project was received by the European Union's Horizon 2020 research and innovation programme under Grant No. 686098 (SmartNanoTox) and FFIKA, Focused Research Effort on Chemicals in the Working Environment from the Danish Government.

\section{Availability of data and materials}

The datasets analyzed during the present study are available from the corresponding author on reasonable request.

\section{Declarations}

\section{Ethics approval and consent to participate}

All experimental procedures followed the handling guidelines established by the Danish government and permits from the Experimental Animal Inspectorate (No. 2015-15-0201-00465). Prior to the study, the experimental protocols were approved by the local Animal Ethics Council.

\section{Consent for publication}

Not applicable.

\section{Competing interests}

The authors declare no competing interests.

\section{Author details}

${ }^{1}$ National Research Centre for the Working Environment, Copenhagen, Denmark. ${ }^{2}$ Comprehensive Pneumology Center (CPC)/Institute of Lung Biology and Disease (ILBD) Helmholtz Zentrum München, Neuherberg, Germany.

${ }^{3}$ DTU Food, Technical University of Denmark, Kgs. Lyngby, Denmark.
Received: 29 April 2021 Accepted: 12 October 2021

Published online: 30 October 2021

\section{References}

1. Ferrari AC, Bonaccorso F, Fal'ko V, Novoselov KS, Roche S, Boggild P, et al. Science and technology roadmap for graphene, related two-dimensional crystals, and hybrid systems. Nanoscale. 2015;7(11):4598-810. https://doi. org/10.1039/c4nr01600a.

2. Vance ME, Kuiken T, Vejerano EP, McGinnis SP, Hochella MF Jr, Rejeski D, et al. Nanotechnology in the real world: Redeveloping the nanomaterial consumer products inventory. Beilstein J Nanotechnol. 2015;6:1769-80. https://doi.org/10.3762/bjnano.6.181.

3. Sajid Ml, Jamshaid U, Jamshaid T, Zafar N, Fessi H, Elaissari A. Carbon nanotubes from synthesis to in vivo biomedical applications. Int J Pharm. 2016;501(1-2):278-99. https://doi.org/10.1016/j.ijpharm.2016.01.064.

4. Halappanavar S, van den Brule S, Nymark P, Gate L, Seidel C, Valentino S, et al. Adverse outcome pathways as a tool for the design of testing strategies to support the safety assessment of emerging advanced materials at the nanoscale. Part Fibre Toxicol. 2020;17(1):16. https://doi.org/10.1186/ s12989-020-00344-4.

5. Boraschi D, Italiani P, Palomba R, Decuzzi P, Duschl A, Fadeel B, et al. Nanoparticles and innate immunity: new perspectives on host defence. Semin Immunol. 2017;34:33-51. https://doi.org/10.1016/j.smim.2017.08.013.

6. Farrera C, Fadeel B. It takes two to tango: understanding the interactions between engineered nanomaterials and the immune system. Eur J Pharm Biopharm. 2015;95 Pt A:3-12. https://doi.org/10.1016/j.ejpb.2015. 03.007

7. Fadeel B. Clear and present danger? Engineered nanoparticles and the immune system. Swiss Med Wkly. 2012;142:w13609. https://doi.org/10. 4414/smw.2012.13609.

8. Akira S, Uematsu S, Takeuchi O. Pathogen recognition and innate immunity. Cell. 2006;124(4):783-801. https://doi.org/10.1016/j.cell.2006.02.015.

9. Arora S, Ahmad S, Irshad R, Goyal Y, Rafat S, Siddiqui N, et al. TLRs in pulmonary diseases. Life Sci. 2019;233:116671. https://doi.org/10.1016/j. Ifs.2019.116671.

10. Lafferty El, Qureshi ST, Schnare M. The role of toll-like receptors in acute and chronic lung inflammation. J Inflamm. 2010;7:57. https://doi.org/10. 1186/1476-9255-7-57

11. Lu YC, Yeh WC, Ohashi PS. LPS/TLR4 signal transduction pathway. Cytokine. 2008;42(2):145-51. https://doi.org/10.1016/j.cyto.2008.01.006

12. Erridge $C$. Endogenous ligands of TLR2 and TLR4: agonists or assistants? J Leukoc Biol. 2010;87(6):989-99. https://doi.org/10.1189/jlb.1209775.

13. Roh JS, Sohn DH. Damage-associated molecular patterns in inflammatory diseases. Immune Netw. 2018;18(4):e27. https://doi.org/10.4110/in.2018. 18.e27

14. Cronin JG, Jones N, Thornton CA, Jenkins GJS, Doak SH, Clift MJD. Nanomaterials and innate immunity: a perspective of the current status in nanosafety. Chem Res Toxicol. 2020;33(5):1061-73. https://doi.org/10. 1021/acs chemrestox.0c00051.

15. Cui X, Wan B, Yang Y, Xin Y, Xie YC, Guo LH, et al. Carbon nanomaterials stimulate HMGB1 release from macrophages and induce cell migration and invasion. Toxicol Sci. 2019;172(2):398-410. https://doi.org/10.1093/ toxsci/kfz190.

16. Tsai CY, Lu SL, Hu CW, Yeh CS, Lee GB, Lei HY. Size-dependent attenuation of TLR9 signaling by gold nanoparticles in macrophages. J Immunol. 2012;188(1):68-76. https://doi.org/10.4049/jimmunol.1100344.

17. Becker S, Dailey L, Soukup JM, Silbajoris R, Devlin RB. TLR-2 is involved in airway epithelial cell response to air pollution particles. Toxicol Appl Pharmacol. 2005;203(1):45-52. https://doi.org/10.1016/j.taap.2004.07.007.

18. Cheng $\mathrm{N}$, He R, Tian J, Ye PP, Ye RD. Cutting edge: TLR2 is a functional receptor for acute-phase serum amyloid A. J Immunol. 2008;181(1):22-6. https://doi.org/10.4049/jimmunol.181.1.22.

19. Sack GH Jr. Serum amyloid A—a review. Mol Med. 2018;24(1):46. https:// doi.org/10.1186/s10020-018-0047-0.

20. Hadrup N, Zhernovkov V, Jacobsen NR, Voss C, Strunz M, Ansari M, et al. Acute phase response as a biological mechanism-of-action of (nano) particle-induced cardiovascular disease. Small. 2020. https://doi.org/10. 1002/smll.201907476. 
21. Halappanavar S, Jackson P, Williams A, Jensen KA, Hougaard KS, Vogel U, et al. Pulmonary response to surface-coated nanotitanium dioxide particles includes induction of acute phase response genes, inflammatory cascades, and changes in microRNAs: a toxicogenomic study. Environ Mol Mutagen. 2011;52(6):425-39. https://doi.org/10.1002/em.20639.

22. Sattler C, Moritz F, Chen S, Steer B, Kutschke D, Irmler M, et al. Nanoparticle exposure reactivates latent herpesvirus and restores a signature of acute infection. Part Fibre Toxicol. 2017;14(1):2. https://doi.org/10.1186/ s12989-016-0181-1.

23. Andre E, Stoeger T, Takenaka S, Bahnweg M, Ritter B, Karg E, et al. Inhalation of ultrafine carbon particles triggers biphasic pro-inflammatory response in the mouse lung. Eur Respir J. 2006;28(2):275-85. https://doi. org/10.1183/09031936.06.00071205.

24. Ridker PM, Hennekens CH, Buring JE, Rifai N. C-reactive protein and other markers of inflammation in the prediction of cardiovascular disease in women. N Engl J Med. 2000;342(12):836-43. https://doi.org/10.1056/ NEJM200003233421202.

25. Saber AT, Jacobsen NR, Jackson P, Poulsen SS, Kyjovska ZO, Halappanavar $\mathrm{S}$, et al. Particle-induced pulmonary acute phase response may be the causal link between particle inhalation and cardiovascular disease. Wiley Interdiscip Rev Nanomed Nanobiotechnol. 2014;6(6):517-31. https://doi. org/10.1002/wnan.1279.

26. Turabekova M, Rasulev B, Theodore M, Jackman J, Leszczynska D, Leszczynski J. Immunotoxicity of nanoparticles: a computational study suggests that CNTs and C60 fullerenes might be recognized as pathogens by Toll-like receptors. Nanoscale. 2014;6(7):3488-95. https://doi.org/10.1039/ c3nr05772k.

27. Mukherjee SP, Bondarenko O, Kohonen P, Andon FT, Brzicova T, Gessner I, et al. Macrophage sensing of single-walled carbon nanotubes via Toll-like receptors. Sci Rep. 2018;8(1):1115. https://doi.org/10.1038/ s41598-018-19521-9.

28. Ng CT, Yip GWC, Chen ES, Poh WYR, Bay BH, Yung LYL. Gold nanoparticles induce serum amyloid A 1-Toll-like receptor 2 mediated NF-kB signaling in lung cells in vitro. Chem Biol Interact. 2018;289:81-9. https://doi.org/ 10.1016/j.cbi.2018.04.022.

29. Bourdon JA, Saber AT, Jacobsen NR, Jensen KA, Madsen AM, Lamson JS, et al. Carbon black nanoparticle instillation induces sustained inflammation and genotoxicity in mouse lung and liver. Part Fibre Toxicol. 2012;9:5. https://doi.org/10.1186/1743-8977-9-5.

30. Kyjovska ZO, Jacobsen NR, Saber AT, Bengtson S, Jackson P, Wallin H, et al. DNA damage following pulmonary exposure by instillation to low doses of carbon black (Printex 90) nanoparticles in mice. Environ Mol Mutagen. 2015;56(1):41-9. https://doi.org/10.1002/em.21888.

31. Husain M, Kyjovska ZO, Bourdon-Lacombe J, Saber AT, Jensen KA, Jacobsen NR, et al. Carbon black nanoparticles induce biphasic gene expression changes associated with inflammatory responses in the lungs of C57BL/6 mice following a single intratracheal instillation. Toxicol Appl Pharmacol. 2015;289(3):573-88. https://doi.org/10.1016/j.taap.2015.11. 003.

32. Poulsen SS, Saber AT, Mortensen A, Szarek J, Wu D, Williams A, et al. Changes in cholesterol homeostasis and acute phase response link pulmonary exposure to multi-walled carbon nanotubes to risk of cardiovascular disease. Toxicol Appl Pharmacol. 2015;283(3):210-22. https://doi. org/10.1016/j.taap.2015.01.011.

33. Poulsen SS, Knudsen KB, Jackson P, Weydahl IE, Saber AT, Wallin H, et al. Multi-walled carbon nanotube-physicochemical properties predict the systemic acute phase response following pulmonary exposure in mice. PLoS One. 2017;12(4):174167. https://doi.org/10.1371/journal.pone.01741 67.

34. Poulsen SS, Saber AT, Williams A, Andersen O, Kobler C, Atluri R, et al. MWCNTs of different physicochemical properties cause similar inflammatory responses, but differences in transcriptional and histological markers of fibrosis in mouse lungs. Toxicol Appl Pharmacol. 2015;284(1):16-32. https://doi.org/10.1016/j.taap.2014.12.011.

35. Bengtson S, Knudsen KB, Kyjovska ZO, Berthing T, Skaug V, Levin M, et al. Differences in inflammation and acute phase response but similar genotoxicity in mice following pulmonary exposure to graphene oxide and reduced graphene oxide. PLoS ONE. 2017;12(6):e0178355. https:// doi.org/10.1371/journal.pone.0178355.

36. Poulsen SS, Bengtson S, Williams A, Jacobsen NR, Troelsen JT, Halappanavar S, et al. A transcriptomic overview of lung and liver changes one day after pulmonary exposure to graphene and graphene oxide. Toxicol Appl Pharmacol. 2021;410:115343. https://doi.org/10.1016/j.taap.2020.115343.

37. Poulsen SS, Jacobsen NR, Labib S, Wu D, Husain M, Williams A, et al. Transcriptomic analysis reveals novel mechanistic insight into murine biological responses to multi-walled carbon nanotubes in lungs and cultured lung epithelial cells. PLoS ONE. 2013;8(11):e80452. https://doi. org/10.1371/journal.pone.0080452.

38. Dong J, Porter DW, Batteli LA, Wolfarth MG, Richardson DL, Ma Q. Pathologic and molecular profiling of rapid-onset fibrosis and inflammation induced by multi-walled carbon nanotubes. Arch Toxicol. 2015;89(4):62133. https://doi.org/10.1007/s00204-014-1428-y.

39. Dudek I, Skoda M, Jarosz A, Szukiewicz D. The molecular influence of graphene and graphene oxide on the immune system under in vitro and in vivo conditions. Arch Immunol Ther Exp (Warsz). 2016;64(3):195-215. https://doi.org/10.1007/s00005-015-0369-3.

40. Totlandsdal Al, Refsnes M, Lag M. Mechanisms involved in ultrafine carbon black-induced release of IL-6 from primary rat epithelial lung cells. Toxicol In Vitro. 2010;24(1):10-20. https://doi.org/10.1016/j.tiv.2009.09. 016.

41. Husain M, Wu D, Saber AT, Decan N, Jacobsen NR, Williams A, et al. Intratracheally instilled titanium dioxide nanoparticles translocate to heart and liver and activate complement cascade in the heart of C57BL/6 mice. Nanotoxicology. 2015;9(8):1013-22. https://doi.org/10.3109/17435 390.2014.996192.

42. Erdely A, Hulderman T, Salmen R, Liston A, Zeidler-Erdely PC, SchweglerBerry D, et al. Cross-talk between lung and systemic circulation during carbon nanotube respiratory exposure. Potential Biomark Nano Lett. 2009;9(1):36-43. https://doi.org/10.1021/nl801828z.

43. Ather JL, Ckless K, Martin R, Foley KL, Suratt BT, Boyson JE, et al. Serum amyloid A activates the NLRP3 inflammasome and promotes Th17 allergic asthma in mice. J Immunol. 2011;187(1):64-73. https://doi.org/10. 4049/jimmunol.1100500.

44. Jeyaseelan S, Manzer R, Young SK, Yamamoto M, Akira S, Mason RJ, et al. Induction of CXCL5 during inflammation in the rodent lung involves activation of alveolar epithelium. Am J Respir Cell Mol Biol. 2005;32(6):531-9. https://doi.org/10.1165/rcmb.2005-0063OC.

45. Chen S, Yin R, Mutze K, Yu Y, Takenaka S, Konigshoff M, et al. No involvement of alveolar macrophages in the initiation of carbon nanoparticle induced acute lung inflammation in mice. Part Fibre Toxicol. 2016;13(1):33. https://doi.org/10.1186/s12989-016-0144-6.

46. Barfod KK, Bendtsen KM, Berthing T, Koivisto AJ, Poulsen SS, Segal E, et al. Increased surface area of halloysite nanotubes due to surface modification predicts lung inflammation and acute phase response after pulmonary exposure in mice. Environ Toxicol Pharmacol. 2020;73:103-266. https://doi.org/10.1016/j.etap.2019.103266.

47. Hadrup N, Rahmani F, Jacobsen NR, Saber AT, Jackson P, Bengtson S, et al. Acute phase response and inflammation following pulmonary exposure to low doses of zinc oxide nanoparticles in mice. Nanotoxicology. 2019;13(9):1275-92. https://doi.org/10.1080/17435390.2019.1654004.

48. Hadrup N, Knudsen KB, Berthing T, Wolff H, Bengtson S, Kofoed C, et al. Pulmonary effects of nanofibrillated celluloses in mice suggest that carboxylation lowers the inflammatory and acute phase responses. Environ Toxicol Phar. 2019:66:116-25. https://doi.org/10.1016/j.etap.2019.01.003.

49. Husain M, Saber AT, Guo C, Jacobsen NR, Jensen KA, Yauk CL, et al. Pulmonary instillation of low doses of titanium dioxide nanoparticles in mice leads to particle retention and gene expression changes in the absence of inflammation. Toxicol Appl Pharmacol. 2013;269(3):250-62. https://doi. org/10.1016/j.taap.2013.03.018.

50. Saber AT, Lamson JS, Jacobsen NR, Ravn-Haren G, Hougaard KS, Nyendi AN, et al. Particle-induced pulmonary acute phase response correlates with neutrophil influx linking inhaled particles and cardiovascular risk. PLoS ONE. 2013;8(7):e69020. https://doi.org/10.1371/journal.pone.00690 20.

51. Danielsen PH, Knudsen KB, Strancar J, Umek P, Koklic T, Garvas M, et al. Effects of physicochemical properties of $\mathrm{TiO}_{2}$ nanomaterials for pulmonary inflammation, acute phase response and alveolar proteinosis in intratracheally exposed mice. Toxicol Appl Pharmacol. 2020;386:114-830. https://doi.org/10.1016/j.taap.2019.114830.

52. Erdely A, Liston A, Salmen-Muniz R, Hulderman T, Young SH, Zeidler-Erdely PC, et al. Identification of systemic markers from a 
pulmonary carbon nanotube exposure. J Occup Environ Med. 2011;53(6 Suppl):S80-6. https://doi.org/10.1097/JOM.0b013e31821ad724.

53. De Buck M, Gouwy M, Wang JM, Van Snick J, Opdenakker G, Struyf S, et al. Structure and expression of different serum amyloid A (SAA) variants and their concentration-dependent functions during host insults. Curr Med Chem. 2016;23(17):1725-55. https://doi.org/10.2174/092986732366616 0418114600 .

54. Chakraborty S, Kaur S, Guha S, Batra SK. The multifaceted roles of neutrophil gelatinase associated lipocalin (NGAL) in inflammation and cancer. Biochim Biophys Acta. 2012;1826(1):129-69. https://doi.org/10.1016/j. bbcan.2012.03.008.

55. Poulsen SS, Jackson P, Kling K, Knudsen KB, Skaug V, Kyjovska ZO, et al. Multi-walled carbon nanotube physicochemical properties predict pulmonary inflammation and genotoxicity. Nanotoxicology. 2016;10(9):1263-75. https://doi.org/10.1080/17435390.2016.1202351.

56. Saber AT, Jacobsen NR, Mortensen A, Szarek J, Jackson P, Madsen AM, et al. Nanotitanium dioxide toxicity in mouse lung is reduced in sanding dust from paint. Part Fibre Toxicol. 2012;9:4. https://doi.org/10.1186/ 1743-8977-9-4.

57. Maus U, von Grote K, Kuziel WA, Mack M, Miller EJ, Cihak J, et al. The role of CC chemokine receptor 2 in alveolar monocyte and neutrophil immigration in intact mice. Am J Respir Crit Care Med. 2002;166(3):268-73. https://doi.org/10.1164/rccm.2112012.

58. Heinrich U, Fuhst R, Rittinghausen S, Creutzenberg O, Bellmann B, Koch W, et al. Chronic inhalation exposure of wistar rats and 2 different strains of mice to diesel-engine exhaust, carbon-black, and titanium-dioxide. Inhal Toxicol. 1995;7(4):533-56. https://doi.org/10.3109/08958379509015211.

59. Zhang R, Dai Y, Zhang X, Niu Y, Meng T, Li Y, et al. Reduced pulmonary function and increased pro-inflammatory cytokines in nanoscale carbon black-exposed workers. Part Fibre Toxicol. 2014;11:73. https://doi.org/10. 1186/s12989-014-0073-1.

60. Jackson P, Hougaard KS, Vogel U, Wu D, Casavant L, Williams A, et al. Exposure of pregnant mice to carbon black by intratracheal instillation: toxicogenomic effects in dams and offspring. Mutat Res. 2012;745(12):73-83. https://doi.org/10.1016/j.mrgentox.2011.09.018.

61. Badolato R, Wang JM, Murphy WJ, Lloyd AR, Michiel DF, Bausserman LL, et al. Serum amyloid $\mathrm{A}$ is a chemoattractant: induction of migration, adhesion, and tissue infiltration of monocytes and polymorphonuclear leukocytes. J Exp Med. 1994;180(1):203-9. https://doi.org/10.1084/jem. 180.1.203.

62. Connolly M, Rooney PR, McGarry T, Maratha AX, McCormick J, Miggin SM, et al. Acute serum amyloid $A$ is an endogenous TLR2 ligand that mediates inflammatory and angiogenic mechanisms. Ann Rheum Dis. 2016;75(7):1392-8. https://doi.org/10.1136/annrheumdis-2015-207655.

63. Bengtson S, Kling K, Madsen AM, Noergaard AW, Jacobsen NR, Clausen $\mathrm{PA}$, et al. No cytotoxicity or genotoxicity of graphene and graphene oxide in murine lung epithelial FE1 cells in vitro. Environ Mol Mutagen. 2016;57(6):469-82. https://doi.org/10.1002/em.22017.

64. Lopes J, Inniss WE. Electron microscopic study of lipopolysaccharide from an avian strain of Escherichia coli O18. J Bacteriol. 1970;103(1):238-43. https://doi.org/10.1128/jb.103.1.238-243.1970.

65. Jackson P, Kling K, Jensen KA, Clausen PA, Madsen AM, Wallin H, et al. Characterization of genotoxic response to 15 multiwalled carbon nanotubes with variable physicochemical properties including surface functionalizations in the FE1-Muta(TM) mouse lung epithelial cell line. Environ Mol Mutagen. 2015;56(2):183-203. https://doi.org/10.1002/em. 21922.

66. Modrzynska J, Berthing T, Ravn-Haren G, Jacobsen NR, Weydahl IK, Loeschner $\mathrm{K}$, et al. Primary genotoxicity in the liver following pulmonary exposure to carbon black nanoparticles in mice. Part Fibre Toxicol. 2018;15(1):2. https://doi.org/10.1186/s12989-017-0238-9.

67. Knudsen KB, Berthing T, Jackson P, Poulsen SS, Mortensen A, Jacobsen NR, et al. Physicochemical predictors of multi-walled carbon nanotubeinduced pulmonary histopathology and toxicity one year after pulmonary deposition of 11 different multi-walled carbon nanotubes in mice. Basic Clin Pharmacol Toxicol. 2019;124(2):211-27. https://doi.org/10. 1111/bcpt.13119.

68. Kasai T, Umeda Y, Ohnishi M, Mine T, Kondo H, Takeuchi T, et al. Lung carcinogenicity of inhaled multi-walled carbon nanotube in rats. Part Fibre Toxicol. 2016;13(1):53. https://doi.org/10.1186/s12989-016-0164-2.

69. Mao L, Hu M, Pan B, Xie Y, Petersen EJ. Biodistribution and toxicity of radio-labeled few layer graphene in mice after intratracheal instillation. Part Fibre Toxicol. 2016;13:7. https://doi.org/10.1186/s12989-016-0120-1.

70. Sadauskas E, Wallin H, Stoltenberg M, Vogel U, Doering P, Larsen A, et al. Kupffer cells are central in the removal of nanoparticles from the organism. Part Fibre Toxicol. 2007:4:10. https://doi.org/10.1186/1743-8977-4-10.

71. Chen SN, Tan Y, Xiao XC, Li Q, Wu Q, Peng YY, et al. Deletion of TLR4 attenuates lipopolysaccharide-induced acute liver injury by inhibiting inflammation and apoptosis. Acta Pharmacol Sin. 2021. https://doi.org/ 10.1038/s41401-020-00597-x.

72. Jacobsen NR, Stoeger T, van den Brule S, Saber AT, Beyerle A, Vietti G, et al. Acute and subacute pulmonary toxicity and mortality in mice after intratracheal instillation of $\mathrm{ZnO}$ nanoparticles in three laboratories. Food Chem Toxicol. 2015;85:84-95. https://doi.org/10.1016/j.fct.2015.08.008.

73. Saber AT, Koponen IK, Jensen KA, Jacobsen NR, Mikkelsen L, Moller $P$, et al. Inflammatory and genotoxic effects of sanding dust generated from nanoparticle-containing paints and lacquers. Nanotoxicology. 2012;6(7):776-88. https://doi.org/10.3109/17435390.2011.620745.

74. Hadrup N, Bengtson S, Jacobsen NR, Jackson P, Nocun M, Saber AT, et al. Influence of dispersion medium on nanomaterial-induced pulmonary inflammation and DNA strand breaks: investigation of carbon black, carbon nanotubes and three titanium dioxide nanoparticles. Mutagenesis. 2017;32(6):581-97. https://doi.org/10.1093/mutage/gex042.

75. Jackson P, Lund SP, Kristiansen G, Andersen O, Vogel U, Wallin H, et al. An experimental protocol for maternal pulmonary exposure in developmental toxicology. Basic Clin Pharmacol Toxicol. 2011;108(3):202-7. https:// doi.org/10.1111/j.1742-7843.2010.00644.x.

76. Wallin H, Kyjovska ZO, Poulsen SS, Jacobsen NR, Saber AT, Bengtson S, et al. Surface modification does not influence the genotoxic and inflammatory effects of $\mathrm{TiO}_{2}$ nanoparticles after pulmonary exposure by instillation in mice. Mutagenesis. 2017;32(1):47-57. https://doi.org/10.1093/ mutage/gew046.

\section{Publisher's Note}

Springer Nature remains neutral with regard to jurisdictional claims in published maps and institutional affiliations.

Ready to submit your research? Choose BMC and benefit from:

- fast, convenient online submission

- thorough peer review by experienced researchers in your field

- rapid publication on acceptance

- support for research data, including large and complex data types

- gold Open Access which fosters wider collaboration and increased citations

- maximum visibility for your research: over 100M website views per year

At BMC, research is always in progress.

Learn more biomedcentral.com/submissions 